\title{
ÇATALCA BÖLGESİ SAVUNMA YAPILARI ÜZERİNE BİR DEĞERLENDİRME*
}

\author{
วัต
}

\begin{abstract}
AN EVALUATION ON DEFENSE STRUCTURES IN ÇATALCA REGION*
\end{abstract}
\author{
Melik EFEOĞLU** \\ Kemal Kutgün EYÜPGILLLER***
}

$\underline{\underline{0 Z}}$

Önce kendini, sonra sahip olduğu değerleri dışarıdan gelebilecek tehditleretehlikelere karşı korumak isteyen insanoğlu, tarih boyunca farklı savunma yöntemleri araştırmış ve geliştirmiştir. Tarihsel süreç içinde bir gerekliliğe dönüşen bu arayış, farklı savunma pratiklerinin ve savunma yapılarının ortaya çıkmasına neden olmuştur. Geçmiş medeniyetlerin mimarlık miraslarından olan savunma yapıları toplumların savunma tarihleri ve teknolojileri hakkındaki bilgilere ulaşılmasına olanak sağlar; sosyal, kültürel ve ekonomik yapıları hakkında yorum yapılmasına da katk1 sunar. İlkel dönemlerden başlayarak doğanın çeşitli etkilerinden, yırtıcı hayvanlardan ya da saldırgan gruplardan korunmak amacıyla inşa edilen savunma yapıları, toplumların gelişmişlik düzeyine ve bulunduğu bölgenin coğrafi özelliklerine bağlı olarak farklılık göstermektedir. Bu çalışma kapsamında ele alınan ve Çatalca Bölgesi'nde bulunan savunma yapıları üç farklı dönemin ürünü olduğu gibi, savunma yapılarının tarihsel süreç içinde geçirdiği evrimi yansıtan ender örneklerdendir. Çatalca Bölgesi'nin jeopolitik açıdan önemini ortaya çıkaran bu yapılar Karadeniz'den Marmara Denizi'ne, kuzey-güney yönünde uzanan savunma hatlarını oluşturmaktadır. İnşa edildikleri dönemde, İstanbul'un savunulması için aktif rol üstlenen bu savunma yapıları günümüzde çeşitli koruma sorunlarına bağlı olarak yok olma tehlikesiyle karşı karşıyadır. Bölgedeki tarihi savunma yapılarının sayısı ve çeşidi göz önünde bulundurulduğunda, Çatalca Bölgesi’nin savunma tarihimiz açısından önemi anlaşılmaktadır. Söz konusu savunma yapılarının tarihi ve mimari değerlerinin gün yüzüne çıkarılmasına ve koruma sorunlarına dikkat çekilerek konuyla ilgili farkındalığın arttırılmasına katkı sağlamak hedeflenmiştir.

Anahtar Kelimeler: Askeri Mimari, Savunma Yapısı, Savunma Hatt, Mimari Miras, Koruma, Çatalca

\footnotetext{
* Bu makale İTÜ Lisansüstü Eğitim Enstitüsü Mimarlık Anabilim Dalı, Restorasyon Programı'nda hazırlanmakta olan "Çatalca Bölgesi Savunma Yapıları ve Koruma Sorunları" başlıklı doktora tezinden üretilmiştir.

* This article has been produced from the PhD thesis titled "Defense Structures and Protection Problems in the Çatalca Region" which is being prepared in the Restoration Program of the Department of Architecture of the ITU Institute of Science.

** Arş. Gör., Adana Alparslan Türkeş Bilim ve Teknoloji Üniv., Mimarlık ve Tasarım Fak., Mimarlık Böl. ORCID ID: https://orcid.org/0000-0001-7846-1374 • E-mail: melikefeoglu@gmail.com

*** Prof. Dr., İstanbul Üniversitesi, Mimarlık Fakültesi, Mimarlık Bölümü. ORCID ID: https://orcid.org/0000-0001-9328-7829 • E-mail: keyupgiller@gmail.com
} 


\section{ABSTRACT}

Human beings, who want to protect themselves against threats and dangers that may come from outside, have researched and developed different defense methods throughout history. This search, which has become a necessity in the historical process, has led to the emergence of different defense practices and defense structures. Defense structures, which are one of the important sources that shed light on the experiences of past civilizations and one of the building blocks of the architectural heritage, allow access to information about the defense history and technologies of societies, as well as contribute to comment on their social, cultural and economic structures. These defensive structure, which were built to protect from various effects of nature, predators or aggressive groups starting from the primitive periods, differ depending on the development level of the societies and the geographical features of the region. Changing combat techniques and technologies have accelerated the transformation, renewal and development of defense structures in the process.

Çatalca Region has an important area among the military architectural heritage sites in terms of the originality and diversity of its historical defense structures. The defense structures in the region are cultural properties that represent the military architecture and defense strategy of the period they were built. This study, which investigates the historical defense structures in the Çatalca Region, consists of three sections. In the first part, changes in defense structures through historical process were discussed. Also, the elements that trigger the development of defense structures were briefly handled. In the second part, in parallel with the development of defense structures in the historical course, defense structures in the Çatalca Region were addressed. The history and architectural features of the defense structures in the region were tried to be emphasized. In the last part, a general evaluation was made on these defensive structures and their current situation and the conservation problems identified following the fieldworks were pointed out.

The defense structures discussed in this study and located in the Çatalca Region are the products of three different periods and are rare examples that reflect the evolution of defense structures in the historical process. These structures, which reveal the geopolitical importance of the Çatalca Region, form the defense lines extending from the Black Sea to the Marmara Sea in the north-south direction. These defense structures, which took an active role to defend Istanbul during the period they were built, face the danger of extinction today due to various protection problems. Considering the number and type of historical defense structures in the region, the importance of the Çatalca Region in terms of our defense history is understood. However, the fact that most of the historical defense structures in the region have not been legally protected and comprehensive conservation works have not been carried out for these structures, shows that the awareness about the military architectural heritage is not at the desired level. In this context, it is aimed to bring the historical and architectural values of these defense structures to light and to raise awareness on the issue by drawing attention to conservation problems.

Keywords: Military Architecture, Defense Structure, Line of Defense, Architectural Heritage, Conservation, Çatalca 


\section{GİRIŞ}

Çatalca Bölgesi, Asya ve Avrupa arasında tarih boyunca geçiş noktası ve önemli yolların birleşme yeri olmuştur. Roma İmparatorluğu döneminde inşa edilen Via Egnatia (Sol Kol), Via Militaris (Orta Kol) ve Kuzey Yolu (Sağ Kol) Avrupa’ya yapılan seferlerde, hem kara orduları tarafından hem de ticaret amacıyla kullanılan önemli güzergâhlardır. ${ }^{1}$ Osmanlı Dönemi'nde de mevcut olan bu yollar, devletin merkezi ile eyaletleri arasındaki bağlantının sağlanmasında etkin rol oynamıştır. MÖ VI. yüzyıldan MS XIX. yüzyıla kadar aktif bir şekilde kullanılan bu güzergâhlardan ikisi, Sağ Kol ve Sol Kol Çatalca Bölgesi'nden geçmektedir.2 Ayrıca, XIX. yüzyılda Balkanlar'daki tarım ürünlerinin hızlı ve kolay bir şekilde taşınabilmesi ve olası savaşlarda asker sevkiyatının hızlandırılması amacıyla inşa edilen Rumeli Demiryolları da yine Çatalca Bölgesi'nden geçmektedir. ${ }^{3}$ Bölgenin stratejik bir konumda olması, Karadeniz ve Marmara Denizi'ne kıyısının bulunması ve coğrafi yapısı, tarih boyunca bu bölgeyi doğal bir savunma üssüne dönüştürmüş ve inşa edilecek savunma yapıları için tercih edilen bir yer yapmıştır. Bölgede inşa edilen savunma yapılarının, kent merkezinden 65-70 km batıda olması, savaş dönemlerinde kent merkezinin güvenliği açısından önemli olmuş ve savunma hattındaki birliklerin geri hizmetlerinin hızlı ve güvenli bir şekilde sağlanmasını olanaklı kılmıştır.
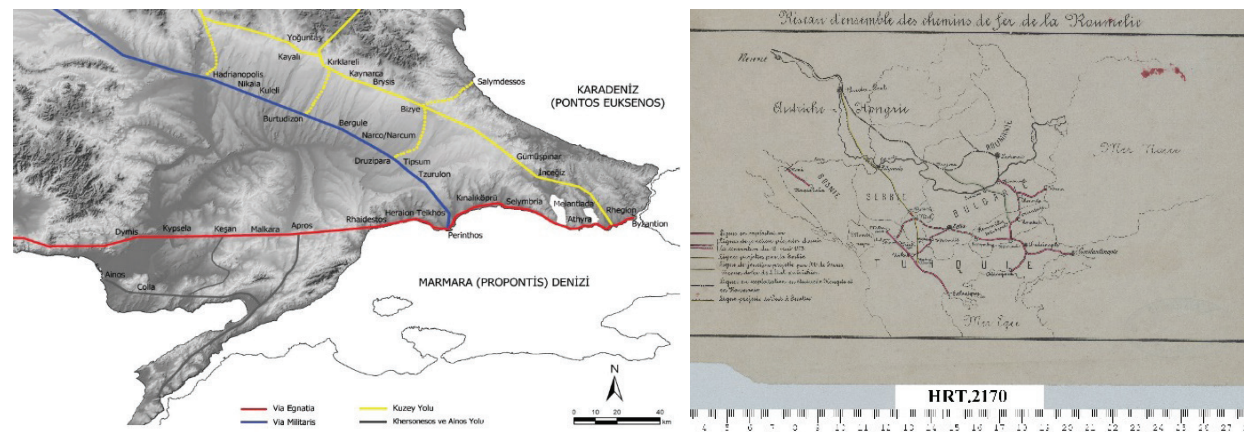

Şekil 1: Solda; Roma Yolları güzergâhı (Karaca, 2020). Sağda; Rumeli Demiryolları haritası (BOA)

Bölgedeki savunma yapılarının tarihi ve mimari değerlerinin gün yüzüne çıkarılması ve korunmalarına yönelik farkındalığın artırılmasına katkı sunması bu çalışmanın en temel amacıdır. Çalışma kapsamında ele alınan tarihi savunma yapıları, yaklaşık $270 \mathrm{~km}^{2}$ 'lik bir alanda, Çatalca ilçesi başta olmak üzere, Büyükçekmece, Arnavutköy ve Silivri ilçelerinde bulunmaktadır. Savunma yapılarının farklı dönemlerin ürünü olmaları, günümüzde Çatalca Bölgesi’nin askeri mimari miras açısından çok katmalı bir yer olmasını sağlamıştır.

1 Altunan, 2005, 2.

2 Karaca, 2020, 29.

3 Kanberoğlu, 2018, 175. 
Çatalca Bölgesi, sahip olduğu tarihi savunma yapılarının özgünlüğü ve çeşitliliği açısından ülkemizin askeri mimari miras alanları içinde önemli bir yer tutmaktadır. Bölgedeki savunma yapıları, inşa edildikleri dönemlerin askeri mimarisini ve savunma stratejisini temsil eden kültür varlıklarıdır. Bu bağlamda, çalışmanın birinci bölümünde savunma yapılarının tarihsel süreç içerisindeki değişimi hakkında kısa bilgilere yer verilmiştir. Savunma yapılarındaki gelişim sürecine paralel olarak, ikinci bölümde ise, Çatalca Bölgesi'ndeki savunma yapıları ele alınmış, yapıların tarihçeleri ve mimari özellikleri aktarılmaya çalışılmıştır. Çalışmanın üçüncü ve son bölümünde de genel bir değerlendirme yapılarak, alan - saha çalışmaları sonucunda tespit edilen koruma sorunlarına dikkat çekilmiştir.

\section{SAVUNMA YAPILARININ GELISȘIMİ}

Avcılık ve toplayıcılıkla hayatlarını sürdüren ilk insanlardan günümüze kadar savunma eylemi yaşamın ayrılmaz bir parçası olmuştur. Doğal malzemelerle yapılmış, ilkel aletler kullanarak kendini korumak isteyen insanoğlu, süreç içinde çok daha güçlü silahlar üretmeye ve sağlam savunma yapıları inşa etmeye başlamıştır. Neolitik Çağ'da yerleşik hayata geçilerek yaşanılan yerlerin ya da bölgelerin güvenliğini ve sürekliliğini sağlamak adına çeşitli önlemler alınmıştır. Yaşam alanlarının bitişik ya da birbirine çok yakın inşa edilmesi, yerleşim bölgelerinin çeperlerinin duvarlarla ya da hendeklerle çevrilmesi, gözetleme kulelerinin yapılması güvenlik kaygılarından dolayı alınmış önlemlerden bazılarıdır. MÖ 8000 yılında kurulmuş olan Jericho (Eriha) kenti, savunma surları ve kuleleriyle tahkim edilmiş ilk şehirlerden biridir. ${ }^{4}$ Aşıklı Höyük (MÖ 8000), Çatalhöyük (MÖ 7400), Tell es-Sawwan (Çakmaktaşı Höyüğü MÖ 6000), Sesklo (MÖ 5800) ve Dimini (MÖ 4800) kendi dönemlerinin savunma sistemini ve aynı zamanda yaşam kültürünü günümüze yansıtan önemli yerlerden bir kaçıdır. Savunulacak alanın önemine ve toplumların sahip olduğu teknolojiye bağlı olarak süreç içinde farklı savunma yapı tipleri ortaya çıkmıştır.

$\mathrm{Bu}$ bağlamda, korunması istenen bir bölgenin savunma duvarları ile çevrilmesi uzun yıllar boyunca kullanılmış etkin savunma yöntemlerinden biridir. Günümüze ulaşan birçok antik ya da ortaçağ kenti farklı yapı malzemeleri ile inşa edilmiş savunma duvarlarına sahiptir. MÖ 1650-700 yıllarında Hitit İmparatorluğu'nun başkenti olan Hattuşaş kenti taş alt yapı üzerine inşa edilmiş kerpiç duvarlara sahipken, erken ortaçağ Avrupa'sında birçok yerleşim yerinin toprak yığma setlerle ya da ahşap kazıklı çitlerle çevrili olduğu bilinmektedir. ${ }^{5}$

Savunma duvarlarında çıkıntı yapacak şekilde, savunma güçlerinin silahlarıyla beraber sığabilecekleri ölçülerde inşa edilen kuleler ise, yüksekliği çapından ya da genişliğinden fazla olan savunma yapılarıdır. Bu yapıları burçlardan ayıran temel özelliklerden biri; burçlar savunma duvarları ile aynı yüksekliğe sahipken, kulelerin daha

4 Müth, Sokolicek, Jansen ve Laufer, 2016, 4.

5 Nossov, 2008, 12; Lepage, 2002, 28-30. 
yüksek kotlara çıkması ve savunma güçleri için daha fazla görüş alanı sağlamasıdır. ${ }^{6}$ Kuleler saldırgan gruplara farklı yönlerden ateş etme imkânı sağladığı gibi savunma güçlerinin göremediği kör noktaları da azaltarak savunma hattının direncini artırırlar. ${ }^{7}$ Olası tehlikeleri önceden fark etmek ve merkezi birliklere haber vermek için savunma duvarlarına bitişik kulelerin dışında, izole olmuş tekil gözetleme kuleleri de süreç içinde inşa edilmiştir.
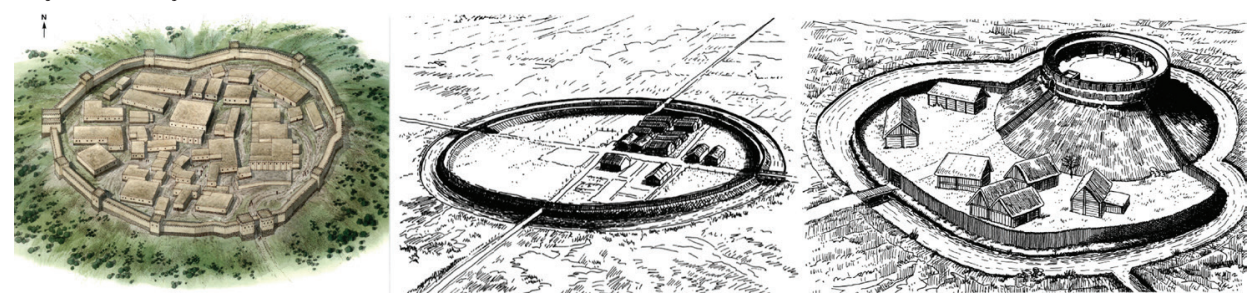

Şekil 2: Solda, Alacahöyük Savunma Duvarları MÖ XIV. yy (Nossov, 2008). Ortada, Toprak yığma setlerle tahkim edilmiş bir köy (8. yy sonlarında)Fyrkat, Danimarka. Sağda, Motte ve Bailey kale tipi (10. yy) (Lapege, 2002).
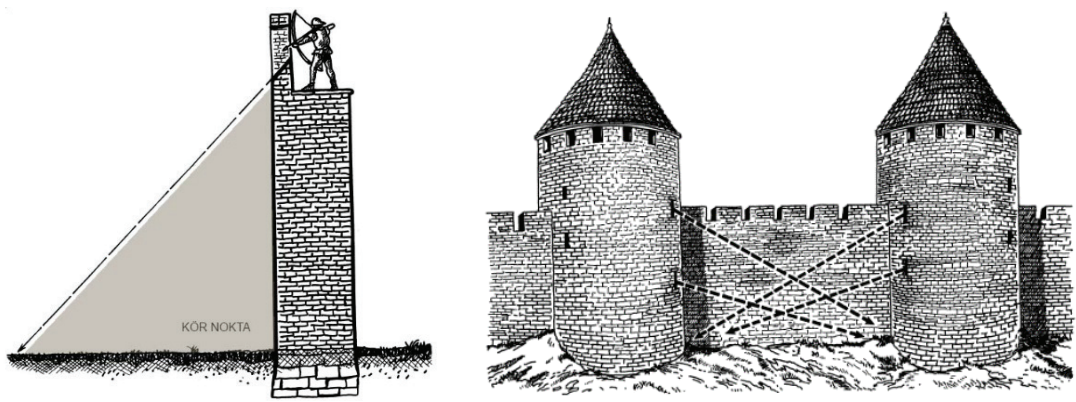

Şekil 3: X -XII. yy bir ortaçağ savunma duvarı ve kuleleri (Lepage, 2002).

İnşa edildiği bölgenin coğrafi özelliklerine göre malzemesi, yapım tekniği ve tasarımı değişebilen fakat kullanım amacı ortak olan bir başka savunma yapısı da kalelerdir. Kalın surlarla, kulelerle ve burçlarla güçlendirilmiş olan kaleler, önemli bir yol güzergâhını, bir yeri ya da bölgeyi korumak amacıyla, gerektiğinde de bulunduğu bölgedeki halkı belirli bir süre en temel ihtiyaçların karşılanabileceği şekilde barındıracak büyüklükte tasarlanırlar. ${ }^{8}$ Ayrıca, içindeki askerlerle saldırgan gruplar için caydırıcılık özelliğine sahip olmaları ve bir saldırı anında merkezden gelen savunma birlikleri için dayanak noktası olmaları, tarih boyunca kendi kendine yetebilen kalelerin temel özelliği olmuştur. ${ }^{9}$

\footnotetext{
6 Keeley, 2007, 67-68.

7 Burke, 2004,128.

8 Sevgen, 1960; Sözen ve Tanyeli, 1986; Hasol, 1990; Ödekan, 1997; Eyice, 2001

9 Parker, 2014, 70.
} 
Stratejik açıdan önemli bir yeri ya da bölgeyi dışarıdan gelecek olası saldırılardan korumak amacıyla inşa edilmiş sabit kalelerin dişında, süreç içerisinde daha küçük ölçekli ve geçici kalelerin de inşa edildiği bilinmektedir. İki farklı tipte, "Havale" ve "Palanka" olarak adlandırılan bu kaleler, kuşatma birlikleri tarafından kullanılan ve ele geçirilmek istenen kalenin yakın bir mesafesine inşa edilen geçici istihkâmlardır. ${ }^{10}$ Kolay ve hızlı bir şekilde, ayrıca; yüksek maliyetli kalıcı kalelere göre daha ucuza mal olan bu yapıların inşa edilmelerindeki en temel amaç, birliklerin düzenini bozmadan kuşatılan kaleyi abluka altına almak ve dışarıdan gelecek yardımları keserek kalenin kısa süre sonra teslim alınmasını sağlamaktır." "Havale"lelerin yapı malzemesi hakkında kaynaklarda kesin bir bilgi olmamasına rağmen, dikdörtgen plan şemasına sahip, toprak setlerle desteklenmiş ahşap çit duvarları olan ve köşelerinde gözetleme kuleleri bulunan "Palanka"larla karakteristik ortak özelliklere sahip olduğu bilinmektedir. ${ }^{2}$
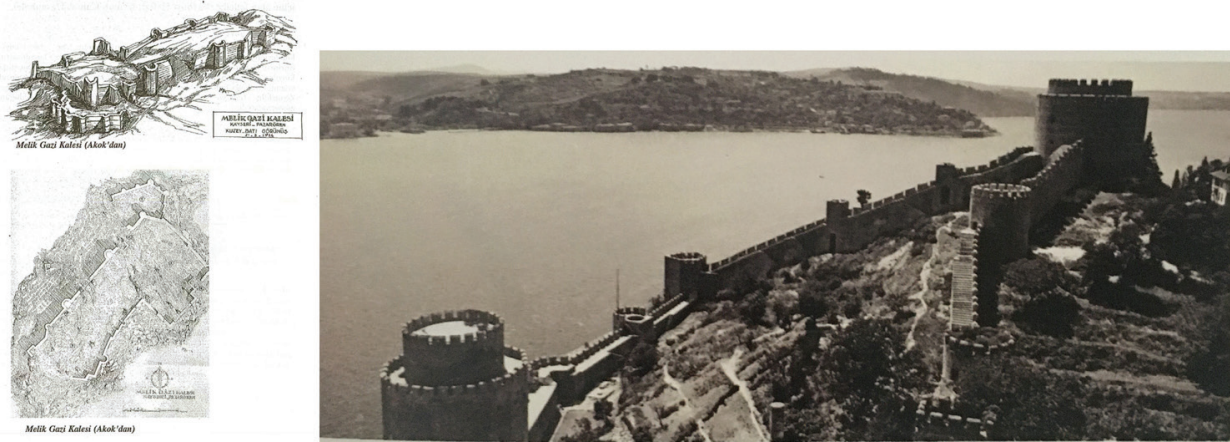

Şekil 4: Solda, Melik Gazi Kalesi, Kayseri (Karpuz, 2004). Sağda, Rumeli Hisarı, İstanbul (Couto, 2016).

XIII. yüzyılda bilim ve teknolojide yaşanan gelişmeler XIV. yüzyıl ve sonrasında ortaya çıkacak yeniliklere zemin hazırlamıştır. ${ }^{13}$ Bu süreçte; haritacılığın gelişmesi, coğrafi keşifler ve yeni araç gereçlerin icadı savaş yöntemlerini de etkilemiştir. XIV. yüzyıla kadar piyadelerin ön planda olduğu ve önemlerinin arttığı uzun bir süreçten sonra, ateşli ağır silahların kullanımının artması, savaş tekniklerinin kökten değişmesine ve "müstahkem mevki" olarak bilinen yeni bir savunma tekniğinin ortaya çıkmasına neden olmuştur. ${ }^{14}$ Barut, top ve güçlü silahların ortaya çıkması ve yaygınlaşması savunma yapılarının tasarımında ve yapım tekniğinde köklü değişimlerin-dönüşümlerin yaşanmasına neden olmuştur. Bu kapsamda, topun önemine dikkat çeken ve savunma yapılarında yeni düzenlemelerin olması gerektiğini dile getiren ilk bilim insanlarından biri Mimar Leon

10 Yeler, 2013, 29.

11 Özgüven, 1997, 48.

12 Özgüven, 2001, 2; Yeler, 2013, 29.

13 Gimpel, 2005, 167.

14 Parker, 2014, 7. 
Battista Alberti'dir. Alberti, 1440'lı y1llarda yazmış olduğu "De Re Aedificatoria" adlı eserinde, savunma yapılarının yıldız planlı olması gerektiğini belirtmiştir. ${ }^{15} 1526$ ' da da askeri stratejist ve yazar Niccolo Machiavelli güçlü toplara direnmek için kentlerin tamamının topçu kalesine dönüştürülmesi fikrini ortaya atmıştır. Yüksek sur duvarları yerine daha alçak ve daha kalın duvarlar örerek, açılı burçlar inşa ederek ve tüm sistemi bir hendekle çevreleyerek, etkin savunma yapılarının daha ucuz ve hızlı yapılabileceğini öne sürmüştür. ${ }^{16}$

Savaş taktiklerinin ve teknolojilerinin hızla değiştiği bu süreçte, "Tabyalı Tahkimatlar" olarak bilinen ve bir kısmı toprak altında kalan kâgir savunma yapıları inşa edilmeye başlanmıştır. Yer seçimi ve düşman ordularının geliş yönü, tüm savunma yapılarında olduğu gibi tabyaların inşasında da belirleyici olmuştur. Tabyaların bulunduğu yere göre, açık, yarı açık ve kapalı sistemler geliştirilmiş, açık ve yarı açık sistemlerde düşman ordularının karşı yönden geleceği, kapalı sistemlerde ise her yönden gelme olasılığg düşünülmüştür.

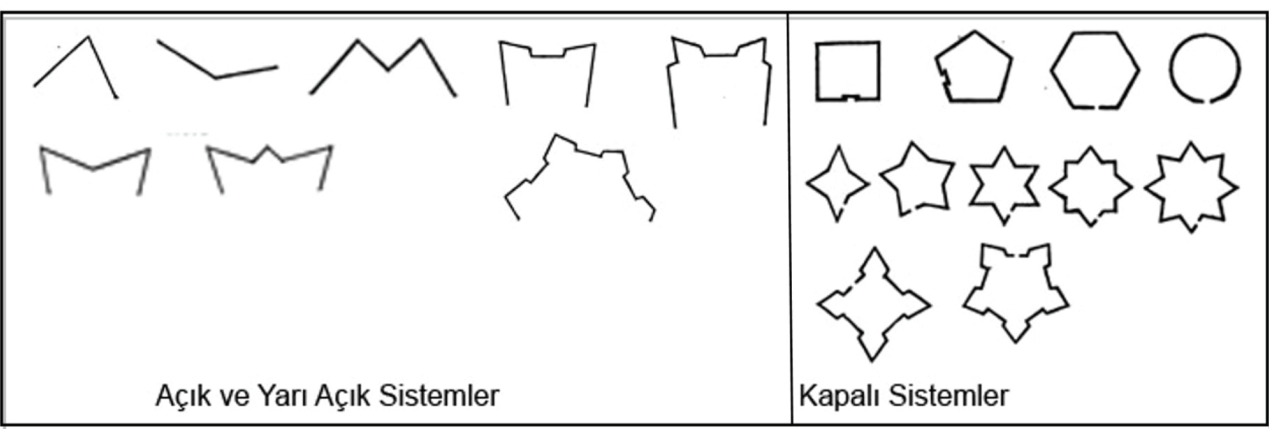

Şekil 5: Tabyalı sistemlerin farklı plan şemaları (Lendy, 1862).

İlk kez 1527(28?)'de Verona'da San Micheli tarafından iki burç inşa edilerek denenen bu sistem, XVI. yüzyıl boyunca İtalyanlar tarafından geliştirilerek, farklı yönlere bakma ve atış yapma imkânı tanıyan açılı burçlarla güçlendirilmiştir. ${ }^{17}$ İtalyanların "Modern Tarz" (alla moderne), farklı ülkelerin "İtalyan Tarzı" (trace italienne) olarak adlandırdıkları bu sistem, İtalya'da ortaya çıktıktan sonra Avrupa'da hızla yayılmış ve her ülke bu savunma sistemine yeni yapısal unsurlar ilave ederek ya da mevcut unsurları değiştirerek sistem üzerinde ölü alan bırakmamaya çalışmıştır.

15 Parker, 2014, 116.

16 Lynch, 2003, 229, 285-286.

17 Lendy, 1862, 490. 


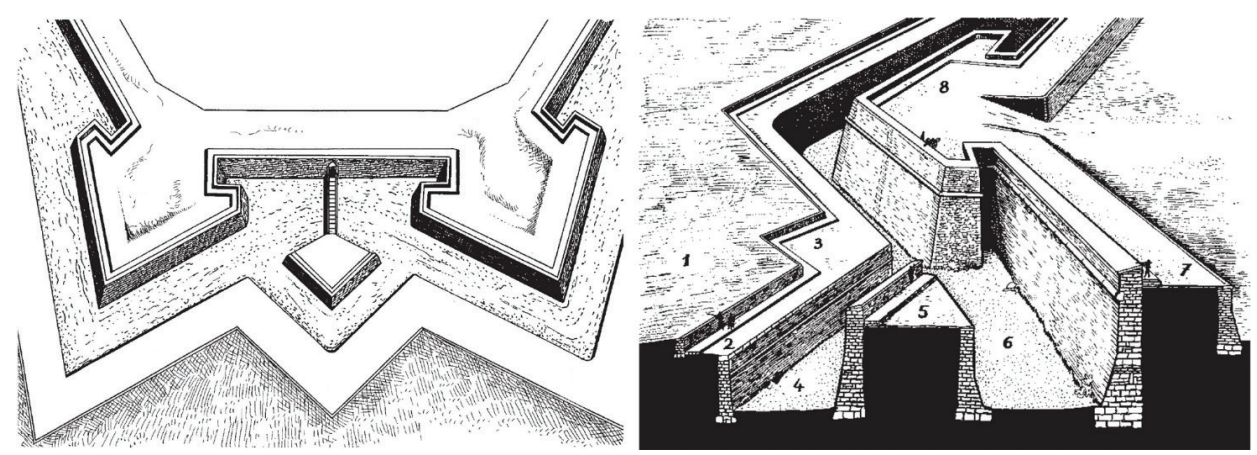

Şekil 6: "İtalyan Tarzı" tabyalı savunma sistemine ait plan ve kesit çizimi, 1- Sahra Şevi, 2Seyirdim Yolu, 3- Top Yeri, 4- Ön Hendek, 5- Yarım-Ay Tabya, 6- Asıl Hendek, 7- Perde-Sur Duvar1, 8- Tabya ((Lepage, 2010).

1566-69 yılları arasında İtalyan Tarzı'na çok benzer bir sistem İspanyol mühendisler tarafından geliştirilmiş ve birçok kentte uygulanmıştır. İspanyol Tarzı olarak bilinen bu sistemin İtalyan Tarzı'ndan tek farkı ise, burçların ve perde duvarların arasındaki açının sabit olmasıdır. ${ }^{18}$ XVI. yüzyılın sonlarında İspanyolların saldırılarından korunmak isteyen Hollandalılar, zamanın gerekliliklerine göre geliştirilen bu sistemde, hendek genişliklerini artırarak ve ana yapıdan bağımsız burçları sisteme dâhil ederek Hollanda Tarzı'nı geliştirmişlerdir. ${ }^{19}$ XVI. yüzyılın sonunda ve XVII. yüzyılda tabyalı sistemlerin gelişmesine katkı sunan bir başka grup ise Fransızlardır. Errard de Bar le Duc 1594 'de yayımladığ 1 "Fortification démontrée et réduite en art" başlıklı eserinde İtalyan Tarzı'nı değiştirmiş ve Fransız Tarzı olarak geliştirdiği bu sistemde burç ve perde duvarlar arasındaki açıyı $75^{\circ}$ 'ye getirmiş ve burçların köşelerine de $90^{\circ}$ 'lik çıkmalar eklemiştir. ${ }^{20} 1629$ 'da Antoine Deville ise burç ve perde duvarlar arasındaki açıyı $90^{\circ}$ 'ye, burçların köşelerine eklenen çıkmaları ise dairesel formlara getirmiştir. ${ }^{21} 1645-46$ ' da ise Blaise Francois Pagan bu sistemde, burçların ve tüm yapıyı saran hendeklerin sayısını ve genişliğini artırmış, hendeklerin içinde bağımsız burçlar tasarlamış ve XVII. yüzyılda tabyalı sistemleri ileri bir düzeye taşıyan Vauban'a öncülük etmiştir. ${ }^{22}$ XVII. yüzyılın ileri gelen askeri mühendislerinden Sébastian le Prestre de Vauban, etkin bir savunma için en az 20.000 asker olmak üzere, savunma yapan bir askere karşılık on kuşatmacı oranını düşünmüş ve geliştirilen tabyalı sistemlerde yapısal değişiklikler yaparak, kendi adıyla anılacak üç farklı sistem oluşturmuştur. ${ }^{23} \mathrm{Bu}$ süreç içerisinde Almanlar da tabyalı sistemleri dönemin silah teknolojisine ve savunma taktiğine uygun olarak yeniden

18 Lendy, 1857, 168.

19 Portlock, 1858, 43.

20 Lendy, 1862, 514.

21 Lendy, 1862, 515.

22 Lendy, 1862, 515.

23 Parker, 2014, 120. 

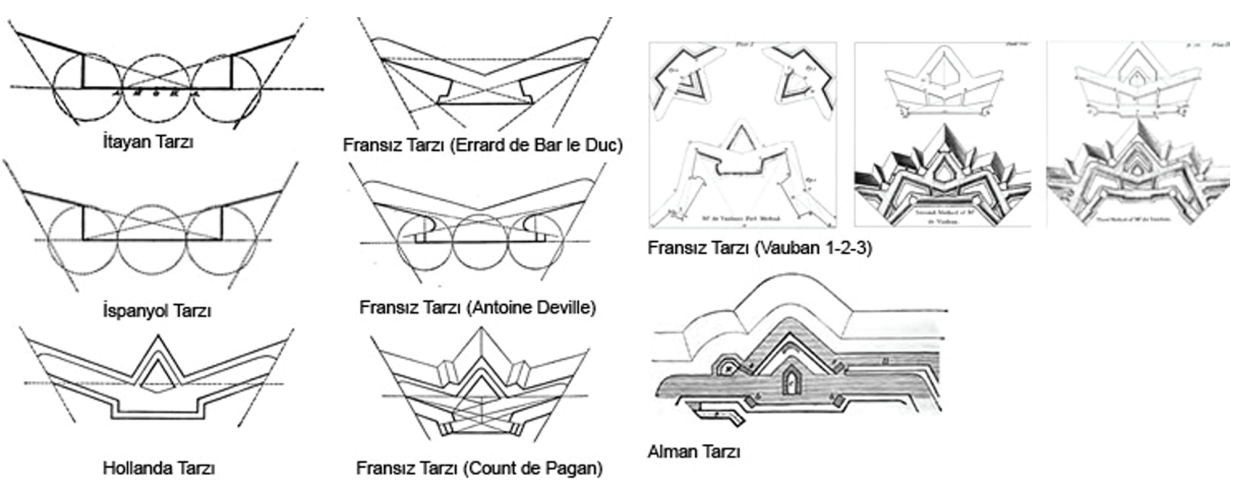

Fransız Tarzı (Vauban 1-2-3)

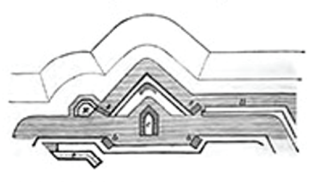

Alman Tarz।

Şekil 7: Tarihsel süreç içerisinde geliştirilmiş tabyalı sistemlerin plan şemaları (Lendy, 1862).

tasarlamış ve XX. yüzyıl savunma yapılarının temellerini atmışlardır. Literatürde Prusya ya da Avusturya Tarzı olarak da bilinen Alman Tarzı tabyalı sistemler 500 metreye varan uzun perde duvarlarına ve çok katlı burçlara sahiptir. ${ }^{24}$

Güçlü ateşli silahların yapılar üzerindeki etkisinin nasıl azaltılacağı ve etkin savunma eyleminin nasıl gerçekleşeceği gibi temel sorunların ayrıntılı matematiksel hesaplamalarla çözülmüş olması tabyalı sistemleri bilimsel yapılar haline dönüştürmüştür. ${ }^{25}$ Ancak, tabyalı sistemlerin inşa edilmeleri için gereken insan gücü ve büyük boyutlardaki hafriyat işleri bu yapıları XIX. yüzyılın sonunda zaman ve maliyet açısından dezavantajlı kılmıştır. Ayrıca, bu yüzyılın sonunda ortaya çıkan nitratlı patlayıcılar ve güçlü silahların dışında, kara, deniz ve hava araçlarının donanım açısından daha zengin üretilmesi tabyalı sistemlerin yetersiz kalmasina da neden olmuştur.

Tarih boyunca kullanılan silahlar ve araçlar ile savunma yapıları arasında karşılıklı etkileşim söz konusu olmuştur. Etkili silahlar, sağlam savunma yapılarının inşa edilmesine, daha sağlam savunma yapıları ise bu yapıları aşmak için gerekli olan güçlü silahların ve araçların ortaya çıkmasına neden olmuştur.

XIX. yüzyılın sonlarında askeri mühendislerin yaptığı teknolojik ve bilimsel araştırmalar, betonarme sığınakların ve kulelerin dönemin güçlü silahlarına karşı en iyi savunmayı sağladığını ortaya koymuştur. ${ }^{26}$ Yabancı literatürde "casemate", "bunker" ya da "pillbox" olarak bilinen ve Türkçe'deki karşılığı "korugan" olan, kalın betonarme duvarlara ve döşemelere sahip ve cephelerinde çok az açıklığı bulunan bu yapılar, belirli bir süre içindeki askerlerin temel ihtiyaçlarını karşılayabilecek şekilde tasarlanmış tekil betonarme savunma yapılarıdır. Birinci Dünya Savaşı'ndan önce birçok ülke betonarme sığınaklar ve bir bölümü toprak altında kalan betonarme piyade kuleleri inşa etmiştir.

24 Lendy, 1857, 180.

25 Keegan, 1993, 326.

26 Donnel, 2008, 8. 
Monolitik betonarme hacimlerden oluşan bu savunma yapıları 1940'ların sonuna kadar yüzlerce farklı tipte inşa edilmiş ve devletlerin sınır bölgelerinde oluşturduğu savunma hatlarına dönüşmüştür. Sovyetler Birliği’nin batıdan gelecek saldırıları önlemek için inşa ettiği Stalin Hattı (1927) ve Molotov Hattı (1939), Fransizların Maginot Hattı (1940) ve Almanlar tarafindan inşa edilen Atlantik Duvarı (1944), İkinci Dünya Savaşı öncesinde inşa edilmiş önemli savunma hatlarından bir kaçıdır.
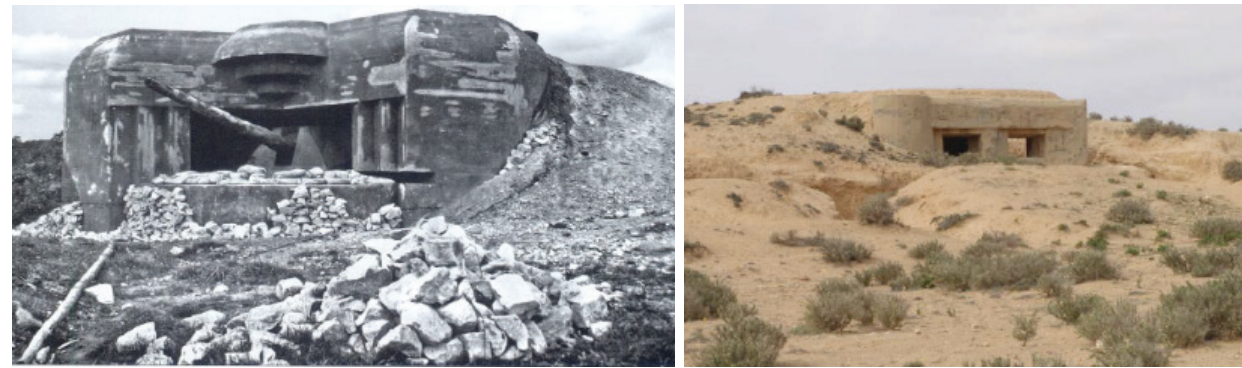

Şekil 8: Solda; Atlantik Duvarı'na ait betonarme korugan (Zaloga, 2007); sağda; Maret Savunma Hattı'na ait betonarme korugan (Ford, 2012).

Özetlenmeye çalışılan bu süreçte, savunma yapılarının değişim ve dönüşümünü tetikleyen faktörlerin başında, gelişen savaş teknolojisi ve değişen taktikler gelmektedir. Tarih boyunca bu değişim ve dönüşüm sürecini her toplum gelişmişlik düzeyine bağl olarak farklı dönemlerde yaşamıştır. Düşmanın güçlü ve etkili toplarının nasıl uzak tutulacağı ya da gelecek zararın nasıl sınırlanacağı, savunma durumundaki toplumların en önemli sorunu olmuştur. Ortaçağın sonuna kadar geçen sürede, etkin savunma yapıları olarak karşımıza çıkan, savunma duvarlarında, kulelerde ve kalelerde, top teknolojisinin gelişmesine ve ateşli silahların kullanım alanının artmasına bağlı olarak köklü değişimler yaşanmıştır. $\mathrm{Bu}$ süreçte, kalelerdeki mevcut ok mazgalları, top mazgallarına dönüştürülmüş, yerleştirilen ağır topların geri tepmesinden kaynaklanan tahribatı ve karşı taraftan gelen top atışlarının etkisini azaltmak için sur duvarlarının yükseklikleri azaltılmış ve kalınlıkları artırılmıştır. Dikdörtgen ya da kare planlı burçlar ve kuleler, dairesel ya da en az beş yüzeyi bulunan poligonal plan şemasına sahip bir yapıya dönüştürülerek savunma hattı üzerinde kör noktaların oluşması engellenmeye çalışılmıştır. Ancak, alınan bu önlemler geleneksel dikey savunma yöntemlerinin ötesine geçememiş ve tabyalı sistemlerin ortaya çıkmasına ve gelişmesine yol açmıştır. XIX. yüzyıl sonu ve XX. yüzyıl başında ağır sanayinin gelişmesi, güçlü ateşli silahların ve araçların üretim hızını artırmış ve savaşlarda kullanım alanını genişletmiştir. Yeni teknoloji karşısında tabyalı sistemlerin de yetersiz kalması, tabyalara göre daha hızlı ve kolay inşa edilebilen betonarme koruganların, devletlerin stratejik açıdan önemli gördükleri yerlerde inşa edilmesine neden olmuştur. 


\section{2. ÇATALCA BÖLGESI'NDEKİ SAVUNMA YAPILARI}

İstanbul'un savunulmasında önemli katkıları olan Çatalca Bölgesi'ndeki savunma yapıları, kendi dönemlerinin savaş tekniklerine ve teknolojilerine uygun olarak inşa edilmiştir. Farklı dönemlerde inşa edilmiş olmaları, bu yapıların tasarım ve yapım tekniği açısından farklı yapısal özelliklere sahip olmalarına neden olmuştur. Ancak, kuzey-güney yönünde Karadeniz ve Marmara Denizi arasında birer savunma hattına dönüşmüş olmaları ya da bir savunma hattı oluşturmak amacıyla inşa edilmiş olmaları bu yapıların temel ortak özelliğidir.

$\mathrm{Bu}$ çalışma kapsamında ele alınan savunma sistemlerinden ilki; Karadeniz Kıyısı'nda Evcik Plajı'ndan başlayıp Silivri ilçesinde sonlanan Anastasius Surları'dır. İkincisi; Terkos Gölü ile Büyükçekmece Gölü arasında bir savunma hattı oluşturan Osmanlı Tabyaları'dır. Son yapı grubu ise; yine Terkos ve Büyükçekmece gölleri arasında II. Dünya Savaşı önlemleri kapsamında inşa edilmiş koruganlar ve farklı işlevlere sahip betonarme yapılardır.

\subsection{Anastasius Surları}

Romalı kaynaklarda “Uzun Duvar" olarak tanımlanan Anastasius Suru, Karadeniz ile Marmara Denizi arasında yaklaşık 56 km uzunluğa sahiptir. Evcik Plajı’ndan başlayıp Silivri'de sonlanan bu savunma duvarının ilk yapım tarihi hakkında günümüzde de devam eden tartışmalar ve farklı görüşler bulunmaktadır. Procopius, I. Anastasius'un (430-518) bu duvarı batıdan gelecek saldırıları engellemek için yaptırdığını belirtmiştir. ${ }^{27}$ Evagrius Scholasticos, Trakya'nın stratejik bir bölgesinde ve İstanbul'a 280 stadyum mesafesinde olan bu duvarı İmparator Anastasius'un yaptırdığını, ayrıca bu duvarın Karadeniz'den Marmara Denizi'ne kadar uzanarak bir yarımada şeklinde olan kenti 420 stadlık bir adaya çevirdiğini ifade etmiştir. ${ }^{28}$ Millingen ise, hem İstanbul'un hem de yakın yerleşim alanlarının güvenliğini sağlamak adına bu duvarın I. Anastasius döneminde (491-518) inşa edildiğini aktarmıştır. ${ }^{29}$ Ancak, Anastasius Surları'nın V. yüzyılın ortalarında inşa edildiğini savunan birçok bilim insanı da bulunmaktadır.

James Crow, Anastasius Suru'nun V. yüzyılda batıdan gelebilecek Bulgar saldırılarına karşı inşa edildiğini aktarır. ${ }^{30}$ Brain Croke, bu savunma duvarının I. Anastasius'dan önce inşa edildiğini iki önemli kaynaktan ("Life of Daniel the Stylite" ve Tarihçi Malchus) yola çıkarak dile getirir. ${ }^{31}$ Marios Philippides, Anastasius Surları'nın aslında 447 yılında inşa edildiğini, fakat I. Anastasius döneminde yeniden yapıldığını belirtir. ${ }^{32}$ Clive Foss ve David Winfield, benzer bir açıklama yaparak, bu duvarın I.

27 Downey, 1971, 293.

28 Bagster, 1846, 172-173.

29 Millingen, 1899, 342-343.

30 Crow, 1995, 109, 112.

31 Croke, 1981, 61.

32 Philippides, 2011, 298. 
Anatasios tarafından yeniden yapıldığını aktarır. ${ }^{33}$ Michael Whitby ise, İmparator Theodosios ile Hunlar arasında 447 yılında gerçekleşen barıştan hemen sonra inşa edildiğini, 478 yılının Ağustos ve Eylül aylarında yaşanan şiddetli depremlerin bu duvara ciddi zararlar verdiğini ifade eder. ${ }^{34}$

Tarihsel süreç içerisinde birçok kez Trakya üzerinden istilaya maruz kalan Konstantinopolis, 421 ve 447 yıllarında Hunlar'ın, 481 ve 486 y1larında Gotlar'in, 490'larda ise Bulgarlar'ın saldırısına uğramış ve ciddi zararlar görmüş̧ür. ${ }^{35}$ I. Anastasius döneminde, imparatorluğun güçlü ve varlıklı zamanlarında bu savunma duvarı kapsamlı bir şekilde onarılmıştır. ${ }^{36}$

Anastasius Surları hakkında önemli bilgilerin birçoğuna farklı tarihlerde bölgeden geçen seyyahların anılarından ulaşmak mümkündür. Petrus Gyllius, 1550'de İstanbul'u ziyaret ettiğinde, İstanbul'un kent dışındaki topraklarının Karadeniz'den Marmara Kıyısı'ndaki Selymbria'ya (Silivri) kadar iki günlük yol uzunluğuna sahip surlarla çevrili olduğunu yazmıştır. ${ }^{37} 1651$ 'de bölgeden geçen Evliya Çelebi, Silivri ile Terkos arasının on bir saat olup, "Silivri'ye gelinceye kadar yedi kat kale duvarı ve hendek hisarı, nice bin yerlerde de burçlar açık seçik görünür" diyerek Anastasius Surları'ndan söz etmiştir. ${ }^{38} 1686$ 'da Silivri'ye gelen Coppin, İstanbul'un dışındaki kırsal alanlarda eğlence evlerinin, güzel bahçelerin ve İmparator Anastasius'un yaptırdığı uzun duvarın harabelerinin göründüğünü söylemektedir. ${ }^{39}$ XVIII. yüzyılda Silivri'yi ziyaret eden Fransız asıllı arkeolog ve gezgin Jean Baptiste LeChevalier ve XIX. yüzyılın başında ziyaret eden Comte Andreossy de anılarında Anastasius Surları'na yer vermişlerdir. ${ }^{40}$

Surlarla ilgili ilk bilimsel çalışmalar ise XIX. yüzyıl sonu ile XX. yüzyıl başlarında dönemin arkeologları tarafindan başlamıştır. Alman arkeolog C. Schuchhardt 1898 yılında Anastasius Surları'nın hem tarihçesine hem de teknik detaylarına yaptı̆̆ çalışmada yer vermiştir. Bu savunma duvarının XI. yüzyılın ortalarına kadar farklı dönemlerde yapılmış onarımlarla ayakta kaldığını ve kent savunmasında önemli bir hat olduğunu aktarmaktadır. ${ }^{41}$ Mansel (1938), “Trakya'nın Kültür ve Tarihi” adlı eserinde bu duvarın inşa edilmesine neden olan olaylar hakkında bilgi vermiş ve duvarla ilgili teknik açıklamalarda bulunmuştur. ${ }^{42}$ Anastasius Surları ile ilgili kapsamlı çalışmalardan

33 Foss ve Winfield, 1986, 130.

34 Whitby, 1985, 560.

35 Crow ve Ricci, 1997, 239.

36 Dikici, 2016, 116-117.

37 Gyllius, 1997,56.

38 Kahraman ve Dağl1, 2006, 385.

39 Coppin, 1686, 102.

40 LeChevalier, 1800, 7; Andreossy, 1818, 159.

41 Schuchhardt, 1901, 109-110.

42 Mansel, 1938, 44. 
birini de arkeoloji, tarih ve sanat tarihi alanlarında çalışmaları bulunan asker kökenli Feridun Dirimtekin gerçekleştirmiştir. Daha önce Schuchhardt tarafindan belgelenen bu sur duvarı, Dirimtekin tarafindan daha kapsamlı bir şekilde tekrar ele alınmıştır. ${ }^{43}$ Dirimtekin, yapmış olduğu çalışmasında sur duvarının yapım tekniği ve malzemesiyle ilgili açıklamalarını kroki ve ölçekli çizimlerle desteklemiştir. ${ }^{44}$
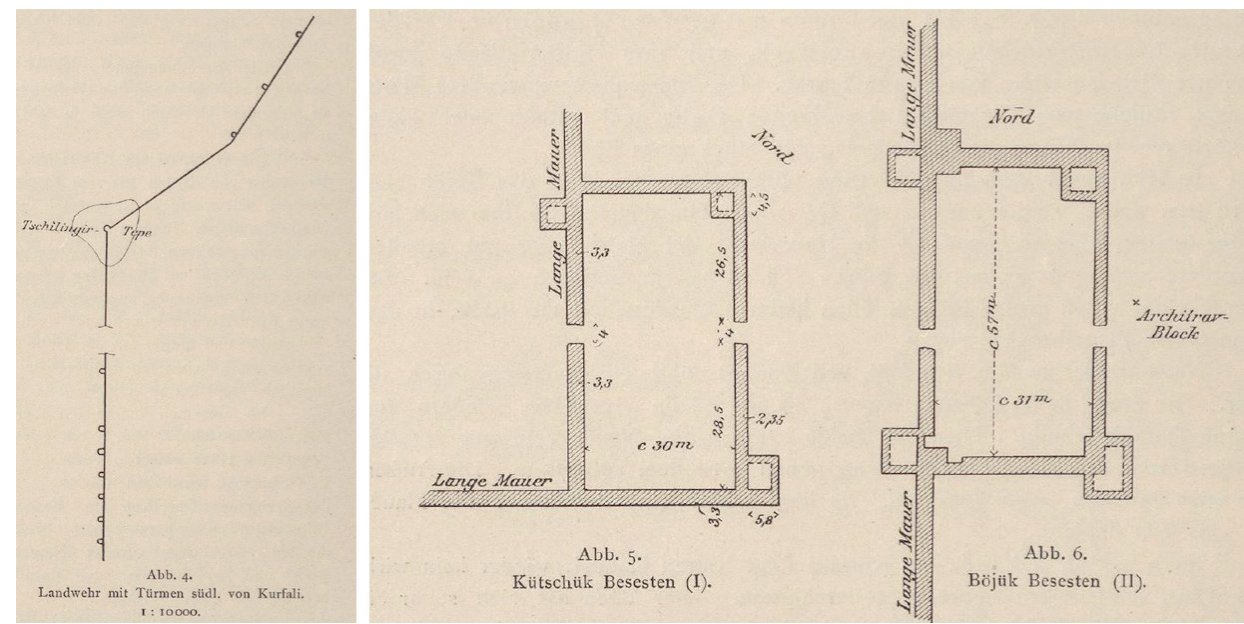

Şekil 9: C. Schuchhardt'ın 1898'de yaptı̆̆ çizimler (Schuchhardt, 1901).
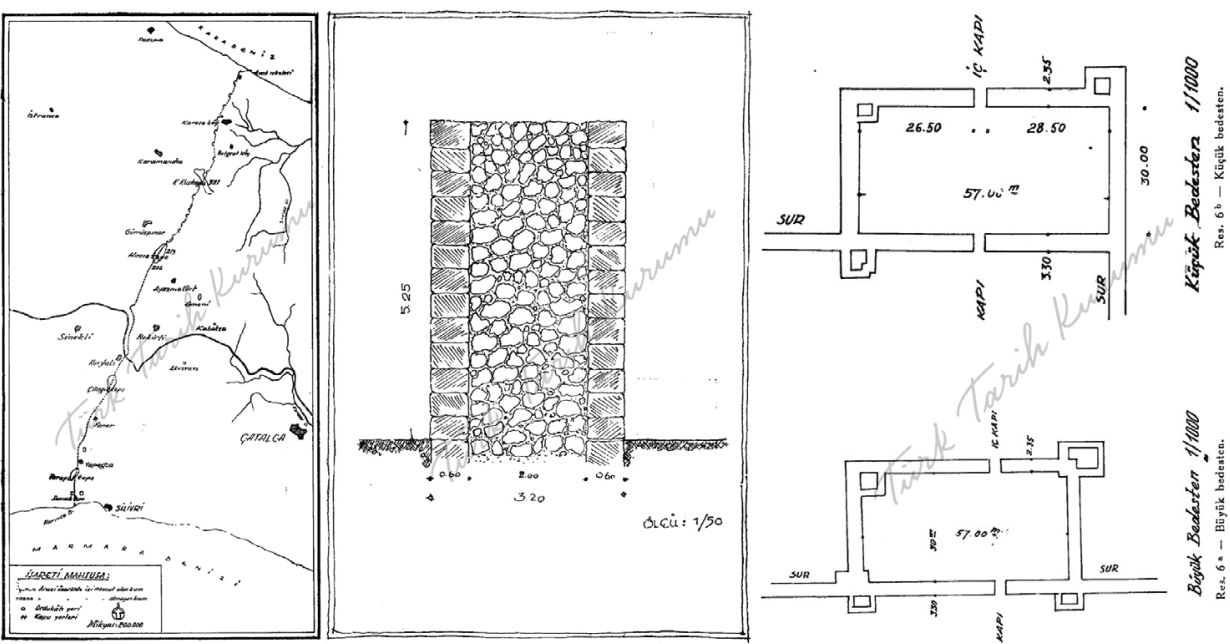

Şekil 10: Dirimtekin tarafından gerçekleştirilmiş tespitler (Dirimtekin, 1948).

43 Eyice, 1980, 266.

44 Dirimtekin, 1948, 1-10. 
Anastasius Surları'yla ilgili bu çalışmalardan sonra 1968 yılına kadar surlarla ilgili bir çalışmaya rastlanmamaktadır. Bölgenin birinci derece askeri yasak bölge ilan edilmesi bu durumun başlıca nedenidir. ${ }^{45}$ Nezih Fıratlı ve ekibinin 1968 ve 1969 yıllarında bölgede yaptıkları arkeolojik kazılarla Anastasius Surları ile ilgili çalışmalara devam edilmiştir. Harrison, “Trakya'da Uzun Duvar” başlıklı makalesinde Nezih Fıratlı ve ekibinin yaptığı çalışmaları ve surlarla ilgili değerlendirmesini alanda yaptığı dört günlük gezi sonrasında yazmıştır. ${ }^{46}$ Anastasius Surları ile ilgili gerçekleştirilmiş son çalışmalar ise 1994 yılında James Crow öncülüğünde başlamıştır. Yaklaşık olarak on yıl süren çalışmalarda surların tespit ve belgeleme çalışmalarının yanı sıra İstanbul'un tarihi su ikmal sistemi de ele alınmıştır.

Anastasius Surları ilk inşa edildiğinde 3-3,5 m kalınlığa ve 10 m yüksekliğe sahip çift cidarlı bir savunma duvarı olarak inşa edilmiştir. Ayrıca, savunma duvarı üzerinde belirli aralıklarla burçlar ve yüksek kuleler, doğu ve batı bölgeleri arasındaki geçişi sağlayan kapılar ve seyirdim yolları bulunmaktadır. ${ }^{47}$ Günümüzde, Karadeniz’e yakın ve Evcik Plajı yolu üzerinde beş metre yüksekliğe ulaşan sur duvarları varlığını sürdürmektedir. Mansel, bu savunma duvarının önünde hendek olmadığını ifade etmiştir. ${ }^{48}$ Ancak yerinde yapılan alan çalışmalarından ve uydu görüntülerinden elde edilmiş verilerde, günümüze ulaşan sur kalıntılarının batısında surlara paralel bir hendek düzeninin olduğu saptanmıştır. Crow ve Ricci, yapmış oldukları tespit çalışmalarında Derviş Kapı bölgesinde yer alan surların önünde iyi korunmuş, 2,5 metre derinliğinde ve 11-13 metre genişliğinde bir hendeğin varlığından söz etmektedirler. ${ }^{49}$

Çift cidarlı bir düzene sahip beden duvarlarının dış tarafında kesme taşlar ya da kaba yonu taşlar kullanılmışken duvarın çekirdeği moloz taşlardan oluşmaktadır. Surların günümüze ulaşan kısımlarında, Evcik Plajı yolu üzerinde yapılan tespitlerde, taşlar $120 \mathrm{~cm}$ uzunluğunda, 35-40 cm yüksekliğinde ve 35-40 cm kalınlığında iken, güneyde Bozyiğit Caddesi'nin batısında ormanlık alan içinde kalan sur duvarlarında bu ölçü 45x40x40 cm ya da 50x45x45 cm olarak değişmektedir. Bağlayıcı malzeme olarak kireç harcının kullanıldığı duvarlarda, mukavemeti artırmaya yönelik herhangi bir hatıl kullanımına rastlanmamıştır.

Anastasius Surları'nın tamamı günümüze kadar ulaşmamış olsa da bu duvarın kuzeyden güneye yaklaşık otuz kilometrelik bölümüne ait kalıntıları günümüzde de varlığını sürdürmektedir. Hem yerinde yapılan alan çalışmaları hem de uydu görüntülerinin sunduğu imkânlarla bu savunma duvarının günümüze ulaşan kısımlarının yerleri tespit edilmiştir. Karadeniz Kıyısı'ndaki Evcik Plajı'nda başlayan surlar topoğrafyaya uyumlu bir şekilde $500 \mathrm{~m}$ batı yönünde ilerledikten sonra güneye doğru devam edip, rakımı

45 Firatl1, 1979, 21-22.

46 Harrison, 1969, 77.

47 Crow ve Ricci, 1997, 245.

48 Mansel, 1938, 44.

49 Crow ve Ricci, 1997, 246. 


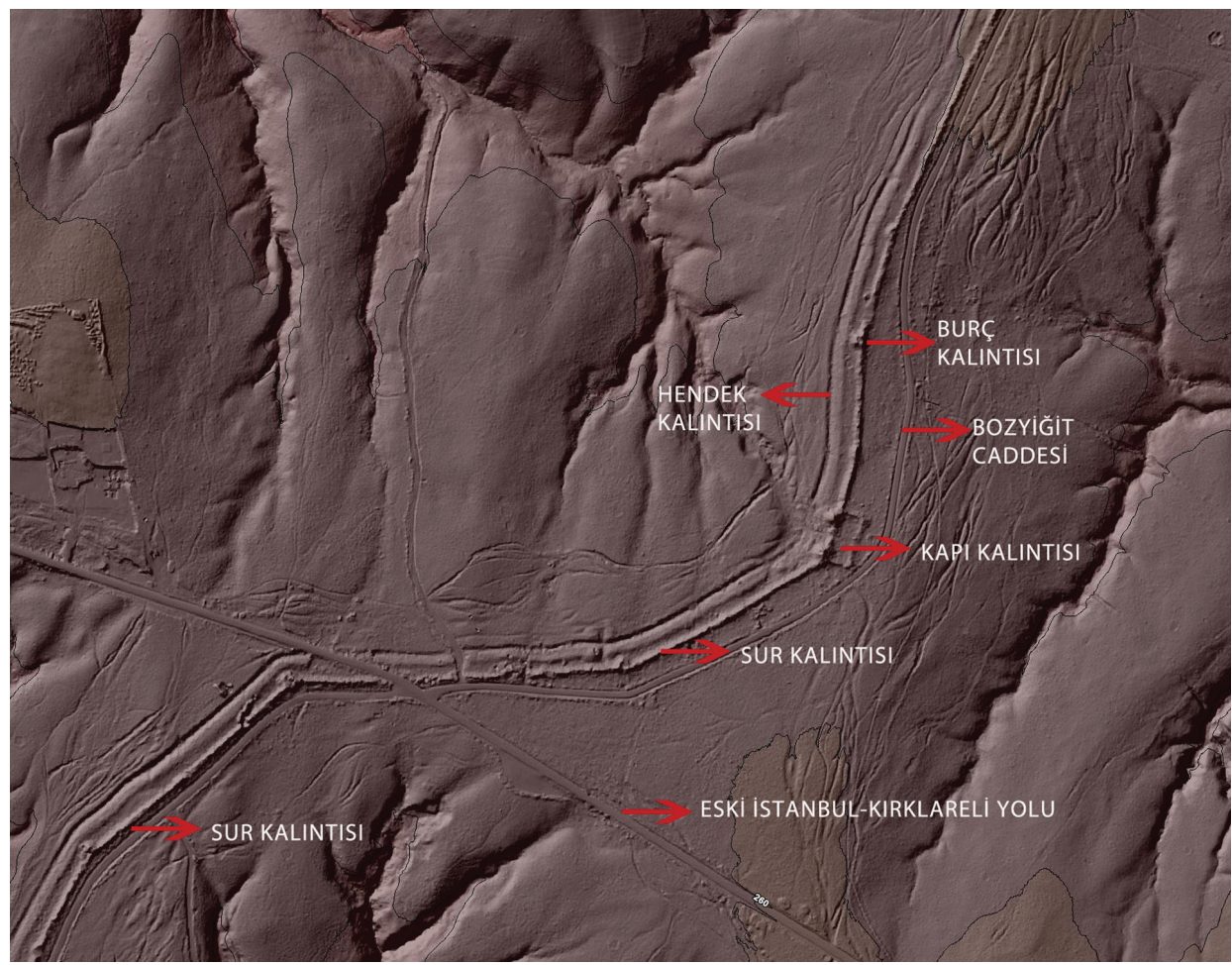

Şekil 11: Anastasius Surları'na ait kalıntılar (https://sehirharitasi.ibb.gov.tr).

112 m olan Hisartepe'ye ulaşır. Evcik Plajı yolundan Karacaköy-Yalıköy yoluna kadar kesintisiz bir şekilde görülebilen surlar $3.18 \mathrm{~km}$ güneye doğru uzanır ve asfalt yolda sonlanır. Sırasıyla, Karacaköy'ün iki km kuzey batısındaki ormanlık alanı ve ardından Balçıkdere ve Karacaköy derelerini aşan surlar 352 m yüksekliğindeki Küçük Kuşkaya Tepesi'ne ulaşır. Surlar güneye doğru Bozyiğit Caddesi'ne paralel olacak şekilde Eski İstanbul-Kırklareli yoluna kadar devam eder. Bozyiğit Caddesi'nin batısında ve yola 5-10 m uzaklığında ormanlık alan içinde sur kalıntılarını görmek mümkündür. Kurfallı Mahallesi'nin üç kilometre kuzeyine kadar bir hat boyunca devam eden sur kalıntıları yerleşim alanlarının başlamasıyla son bulur. Dirimtekin, yapmış olduğu tespit çalışmalarında surların Kurfallı'nın içinden geçip Çilingirtepe'ye ulaştığını, Kurfallı - Fenerköyü'nü takip edip Sancaktepe'ye geldiğini ve Karınca Burnu'nda Marmara Denizi'nde sonlandığını yazar. ${ }^{50}$

50 Dirimtekin, 1948, 3-4. 

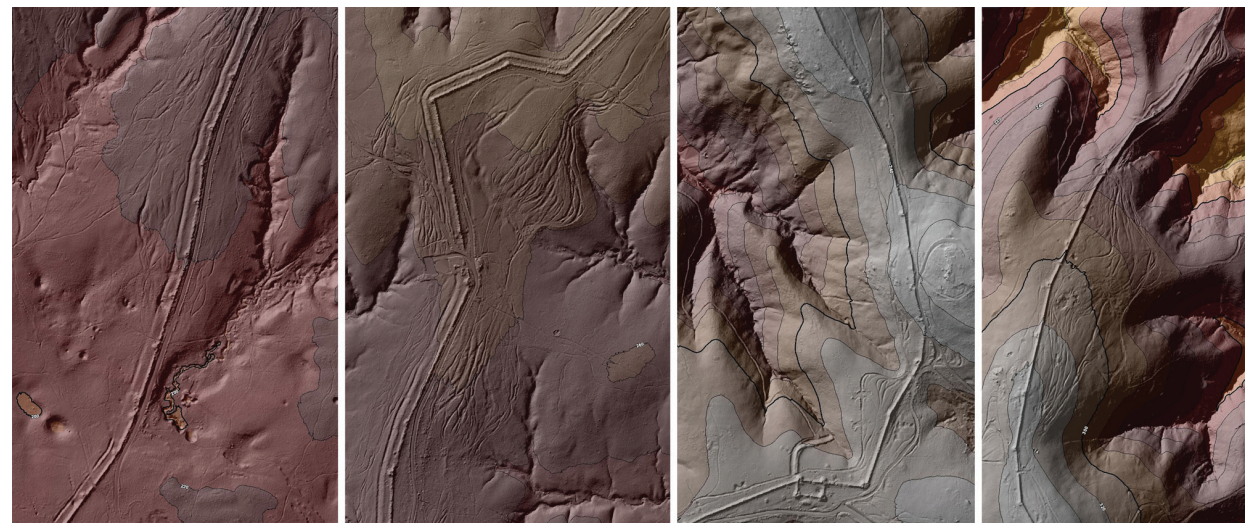

Şekil 12: Anastasius Surları'nın kabartma harita üzerindeki izleri (https://sehirharitasi.ibb.gov.tr).
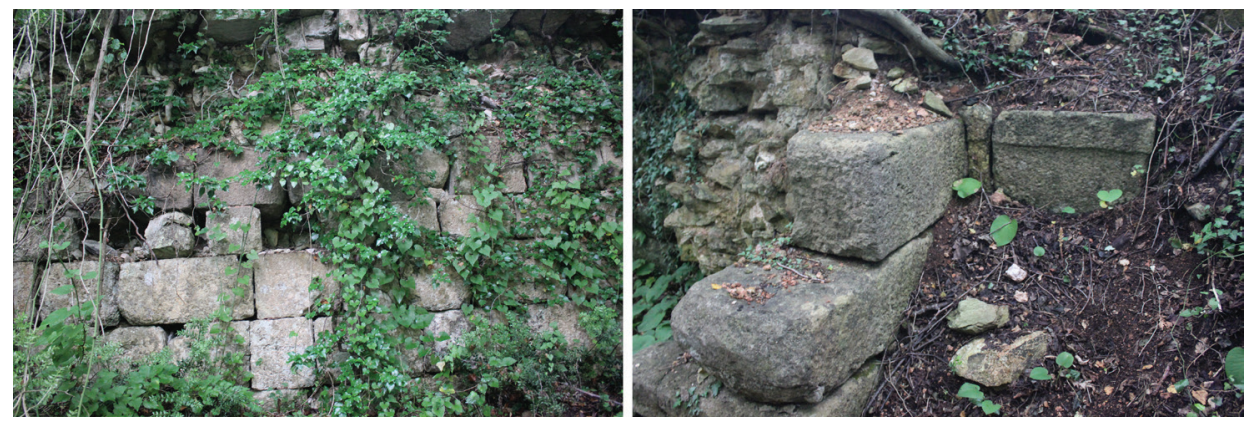

Şekil 13: Anastasius Surları kalıntıları (M. Efeoğlu, 2019).
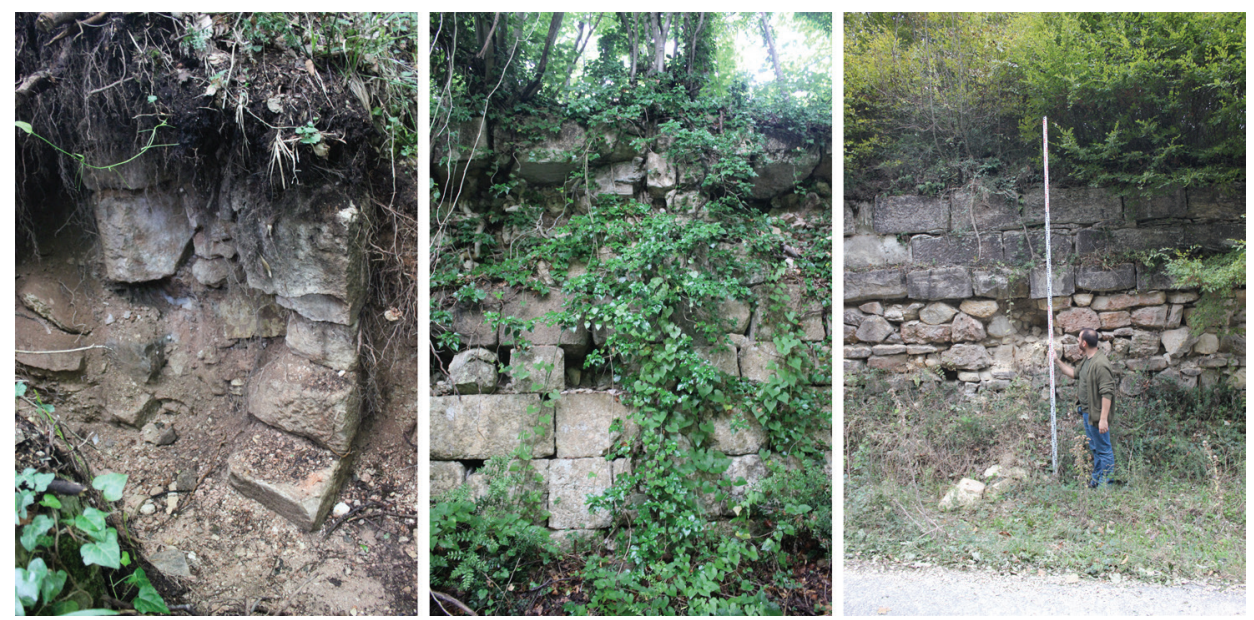

Şekil 14: Anastasius Surları kalıntıları (M. Efeoğlu, 2019). 


\subsection{Yüzyıl Osmanlı Tabyaları}

Osmanlı yönetiminin XIX. yüzyılda almış olduğu kararlarla, eğitim, sağlık, ekonomi gibi birçok alanda düzenlemeler ve yenilikler yapılmıştır. Bu dönemde orduda yapılan çeşitli düzenlemelerle örgütlenme ve işleyişin yanı sıra savunma sistemlerinde de önemli değişiklikler gerçekleşmiştir. XIX. yüzyılın başlarında modern silah ve donanıma geçilerek ordunun eksikleri giderilmeye çalışılmış, 1885 ve 1888'de Almanya'daki Krupp fabrikalarından alınan ağır toplar, Çanakkale ve İstanbul boğazlarındaki ve Çatalca'daki yeni istihkâmlara yerleştirilmiştir. ${ }^{51}$ Osmanlı, dışarıdan gelebilecek saldırılara karşı ülkenin stratejik açıdan önemli yerlerine; Çanakkale, Edirne, Kırklareli, Erzurum, Kars ve Ardahan kentlerine dönemin savaş tekniklerine uygun yeni savunma yapıları inşa ettirmiştir. Çatalca Bölgesi'nde de Büyükçekmece ve Terkos gölleri arasında bir savunma hattı kurarak batıdan gelecek tehlikelere karşı önlem almıştır. XIX. yüzyılın sonlarında inşa edilen ve kaynaklarda "Çatalca Savunma Hattı" olarak adlandırılan bu hat, birbirinden bağımsız tepe üstü tabyalarından oluşmaktadır. Çatalca Savunma Hattı, yaklaşık olarak beş kilometre derinliğe ve 30 kilometre uzunluğa sahip olup, Osmanlı hizmetindeki bir Alman istihkâmcısı olan Von Bluhm Paşa tarafından 1877'de tasarlanmıştır. ${ }^{52} 1878$ 'de inşa edilmeye başlanan bu savunma hattında 28 tabya bulunurken süreç içinde yeni tabyalar inşa edilerek bu hattın direnci artırılmaya çalışılmıştır.

1878 tarihli bir Osmanlı Arşivi belgesinde, Osmanlı ve Rusya arasında yaşanması muhtemel savaşa karşı, bir Osmanlı paşası ile bir İngiliz mühendisin 1876'da Çatalca Bölgesi'nde keşif yaptığ 1 ve bölgenin haritasının hazırlandığı yazmaktadır. ${ }^{53}$ Ancak, Osmanlı-Rus Savaşı başlayana kadar bölgede tam anlamıyla hazırlıklar yapılmamış ve bir savunma hattı oluşturulmamıştır. Bahsi geçen belgede, yapılması gereken işlerin zamanında yapılmadığı, Osmanlı'nın zor durumda kaldığ1 ve bölgedeki mevzilerin düşman ordularına bırakılarak Osmanlı ordusunun geri çekildiği yazmaktadır. ${ }^{54}$ Bölgedeki istihkâm inşası ancak, 3 Mart 1878'de imzalanan Ayastefanos Antlaşması ile sona eren savaştan sonra hız kazanmıştır. Büyükçekmece ve Terkos gölleri arasında inşa edilen bu savunma hattına ait bilgilerin önemli bir kısmına Ferik Bekir Paşa'nın ${ }^{55}$ hazırlamış olduğu 30 Ekim 1878 tarihli rapordan ulaşmak mümkündür. Ferik Bekir Paşa, hazırladığı raporunda;

- Önceden inşa edilen tabyaların bakımsız ve istihkâmları birbirine bağlayan yolların yapılmamış olduğunu,

- Bölgeden geçen Rus ordusunun mevcut istihkâmlara ciddi zarar verdiğini,

- Savunma hattındaki askerlerin sayıca az olduğunu,

51 Çadırc1, 1989; Erickson, 2013, 21.

52 Hall, 2003, 33.

53 BOA, Y.. PRK. ASK., 2-39.

54 BOA, Y.. PRK. ASK., 2-39.

55 Ferik Bekir Paşa, Mühendishane-i Hümayun'dan mezun olduktan sonra 1249'da istihkâm kaymakamı olmuş ve 1251 'de miralaylığa terfi edip, eğitim amacıyla İngiltere'ye gönderilmiştir. 1256 'da İstanbul'a döndüğünde mirlivalığa terfi etmiş ve Erzurum Bölgesi müfettişliğine tayin edilmiştir. Bk.: Mehmed Esad, Mirat-1 Mühendishane-i Berri-i Hümayun, s. 62-64. 
- Tüm hattın inşası için 40.000 askerin görevlendirilmesi gerektiğini,

- Askerlerin kalabileceği barakaların henüz inşa edilmediğini ancak askerin savunma hattına yakın köylerde kalabileceğini,

- İstihkâmlar arası malzeme sevkiyatı için şimendifer hattının elzem olduğunu,

- Savunma hattının inşası için gereken kazma-kürek vs. gibi malzemelerin yeterli olmadığını, 220 adet top ve bu toplar için döşeme kerestesine, 900 adet beygire, kazamat ve profilleri için keresteye ihtiyaç duyulduğunu yazmıştır.

Ayrıca Ferik Bekir Paşa, hem onarılan hem de yeni inşa edilen tabyalarda yapılan inşaat işlerini bir çizelge şeklinde hazırladığı rapora eklemiştir. ${ }^{56}$

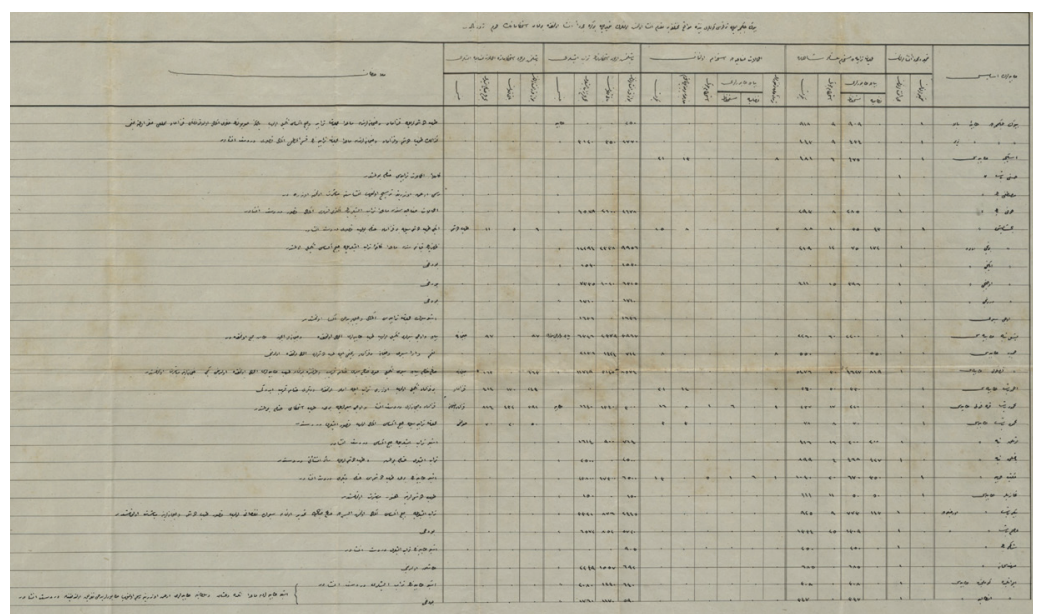

Şekil 15: Tabyalarda devam eden işleri gösteren tablo (BOA, Y.. PRK. ASK., 2-39).

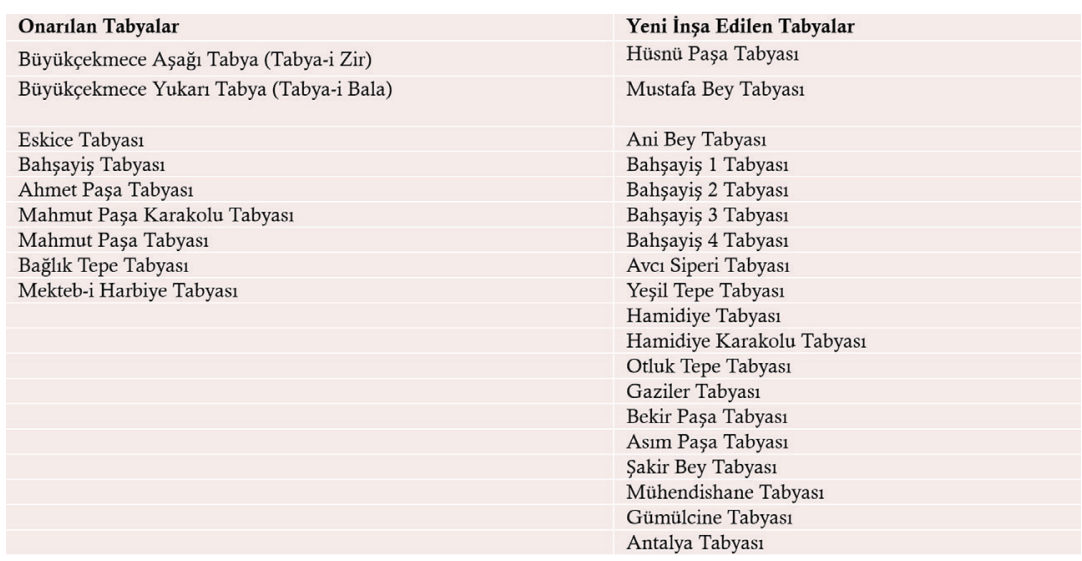

Şekil 16: Ferik Bekir Paşa'nın hazırladığı tabloya göre, onarılan ve yeni inşa edilen tabyalar.

56 BOA, Y.. PRK. ASK., 2-39. 
3 Mart 1880 tarihli bir başka belgede ${ }^{57}$ ise, bölgede inşa edilen savunma hattındaki tabyaların plan ve kesit çizimlerinin, "Çatalca İstihkâmatı İnşa Komisyonu ${ }^{58}$ " tarafından düzenlendiği yazmaktadır. Hazırlanan plan çizimlerinde, 16 farklı bölgede bulunan toplam 83 tabyanın ismi yer almakta ve bölgede inşa edilen tabyaların on farklı plan tipine sahip olduğu anlaşılmaktadır. Çatalca Bölgesi'nde oluşturulan bu savunma hattına ait bilgilerin önemli bir kısmına da XIX. yüzyıl sonu ve XX. yüzyıl başlarında çizilmiş haritalardan ulaşılmaktadır. Bu haritalarda, bölgede inşa edilmiş tabyaların, karakolların, siperlerin ve cephaneliklerin yerlerine, telgraf hatlarının ve yolların nerelerden geçtiğine yer verilmiştir. Erkan-1 Harbiye Matbaası'nda 1800'lerin sonunda basılmış bir haritada Büyükçekmece'den Terkos'a kadar tabyaların yerleri işaretlenmiş ve isimleri belirtilmiştir. 1909 tarihli bir başka haritada ise 28 tabyanın isimleri yazılmış ve krokileri de çizilmiştir.

\begin{tabular}{|c|c|c|}
\hline Numara & Tabyanin Adı & Bölge \\
\hline 1 & Tabya-i Zir & \multirow{2}{*}{$\begin{array}{c}\text { Büyükçekmece } \\
\text { Dairesi }\end{array}$} \\
\hline 2 & Tabya-i Bala & \\
\hline 4 & Eskice Tabyası & \multirow{4}{*}{ Eskice Dairesi } \\
\hline 5 & Hüsnü Paşa Tabyası & \\
\hline 6 & Mustafa Bey Tabyası & \\
\hline 7 & Avni Bey Tabyası & \\
\hline 8 & Aydin Tabyası & \multirow{10}{*}{ Bahşayiş Dairesi } \\
\hline 9 & Arab Tabya & \\
\hline 10 & Nazif Bey Tabyası & \\
\hline 11 & Demiryol Tabyası & \\
\hline 12 & Bahşayiş Tabyası & \\
\hline 13 & Ragıp Bey Tabyası & \\
\hline 14 & Rıza Bey Tabyası & \\
\hline 15 & Hasan Bey Tabyası & \\
\hline 16 & Ahmet Paşa Tabyası & \\
\hline 17 & Saadettin Efendi Tabyası & \\
\hline 18 & Yeşil Tepe Tabyası & \multirow{5}{*}{ Hamidiye Daires } \\
\hline 19 & Halil Bey Tabyası & \\
\hline $20-21$ & Hamidiye Karakolu Tabyası & \\
\hline 22 & Top Tabyası & \\
\hline 23 & Hamidiye Tabyası & \\
\hline 24 & Mahmut Pasa Karakolu Tabyası & \multirow{5}{*}{$\begin{array}{l}\text { Mahmut Paşa } \\
\text { Dairesi }\end{array}$} \\
\hline 25 & Mahmut Paşa Tabyası & \\
\hline 26 & Galip Paşa Tabyası & \\
\hline 27 & Oyuk Tepe Tabyası & \\
\hline 28 & Sancak Tepe Tabyası & \\
\hline
\end{tabular}

Şekil 17: Çatalca İstihkâmatı İnşa Komisyonu'nun düzenlediği raporda, yer alan tabyalar ve bulundukları daireler. (Not: "Numara" başlığı altındaki sayılar, sıra numarası değildir. Orijinal belgede, tabya isimlerinin yanında yer alan numaralardır. Bk. Şekil 18)

57 İstanbul Üniversitesi, Nadir Eserler Kütüphanesi, Demirbaş Numaras1: 93178.

58 Çatalca İstihkâmatı İnşa Komisyonu azaları: Erkan-1 Harbiye Kaymakamı Mehmet Atıf, Erkan-1 Harbiye Miralayı Ali Rıfat, Topçu Mirliva Seyyid Mehmet Asım, Nazır Vekili İstihkâm Mirliva Seyyid Ahmed Sırrı, Erkan-1 Harbiye Mirliva Hüsnü Paşa ve Nazır-1 İstihkâm Ferik Bekir Paşa. 


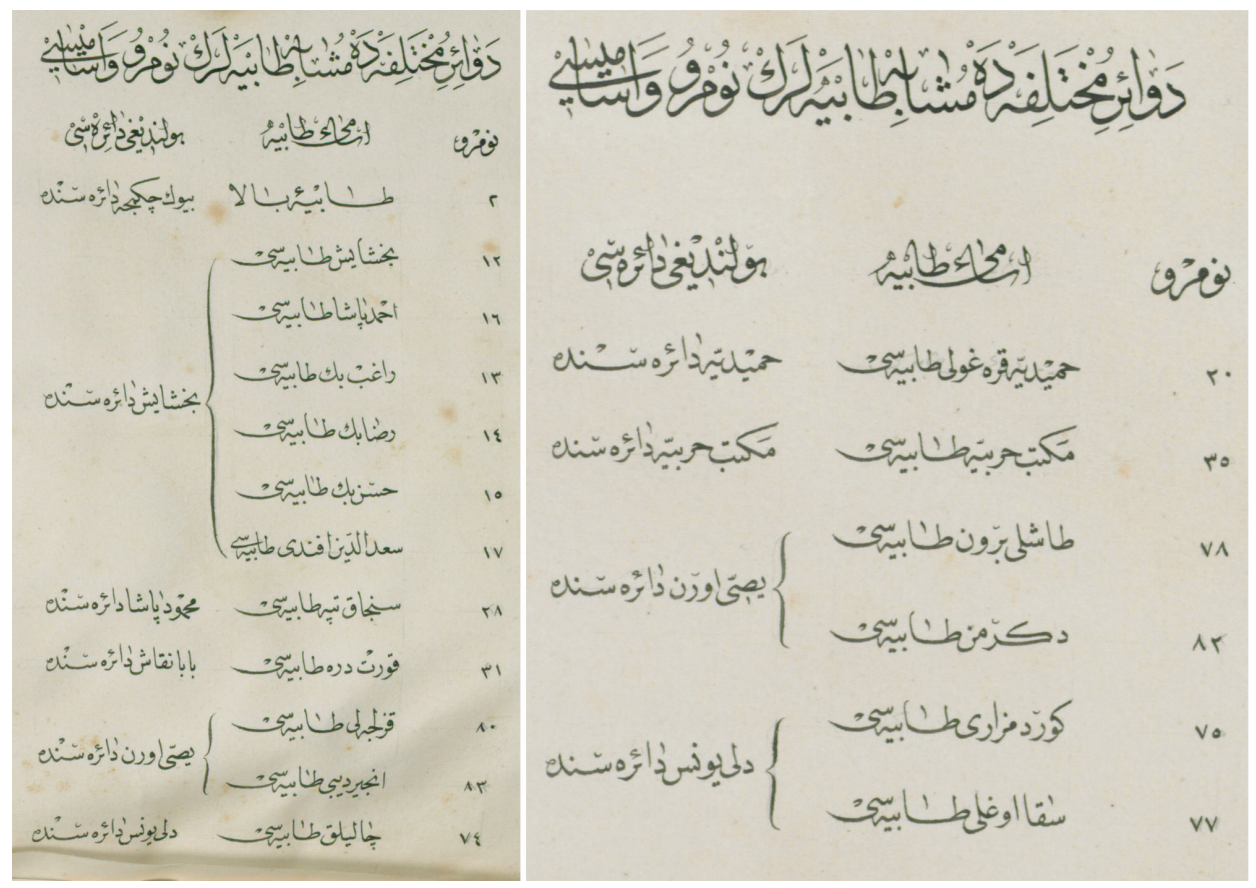

Şekil 18: Çatalca Savunma Hattı'ndaki on sekiz tabyanın, yer aldığı daireler ve numaraları (NEK, 93178).

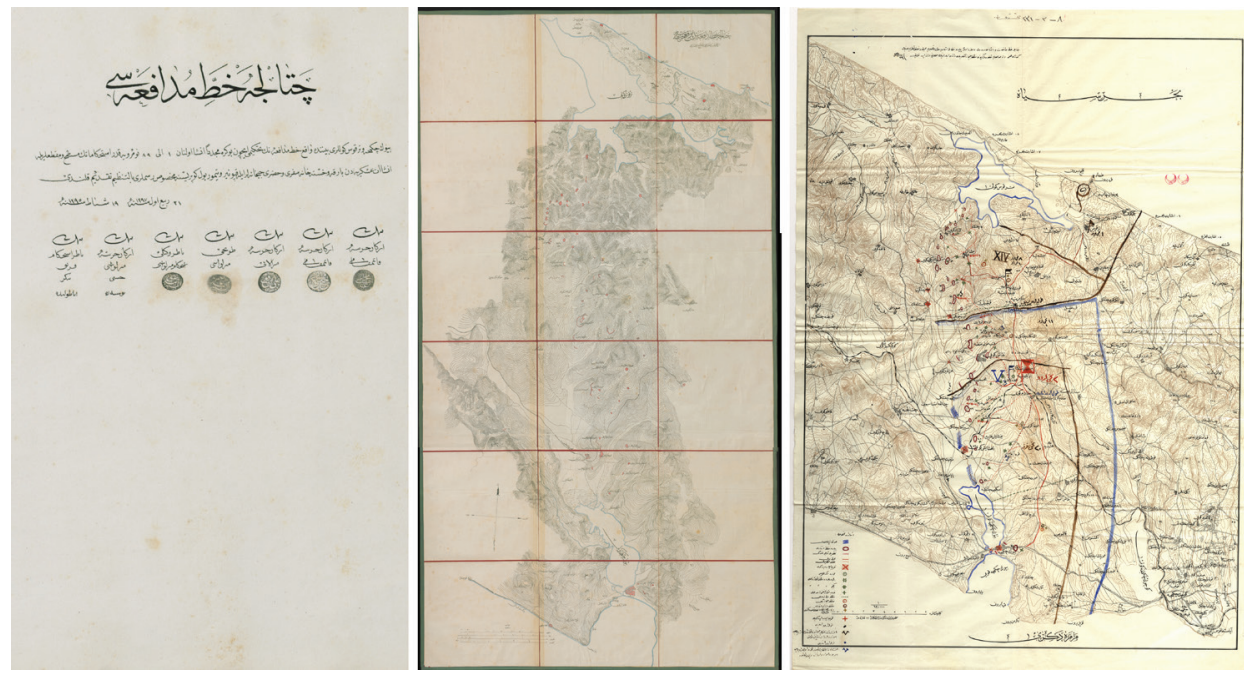

Şekil 19: Solda; Çatalca Savunma Hattına ait 1880 tarihli arşiv belgesi (NEK, 93178), Ortada; Savunma hattı haritası (NEK, 92518), Solda; Çatalca Müstahkem Mevki Durum Haritası (ATASE, $\mathrm{BDH}, 7-616-36)$. 


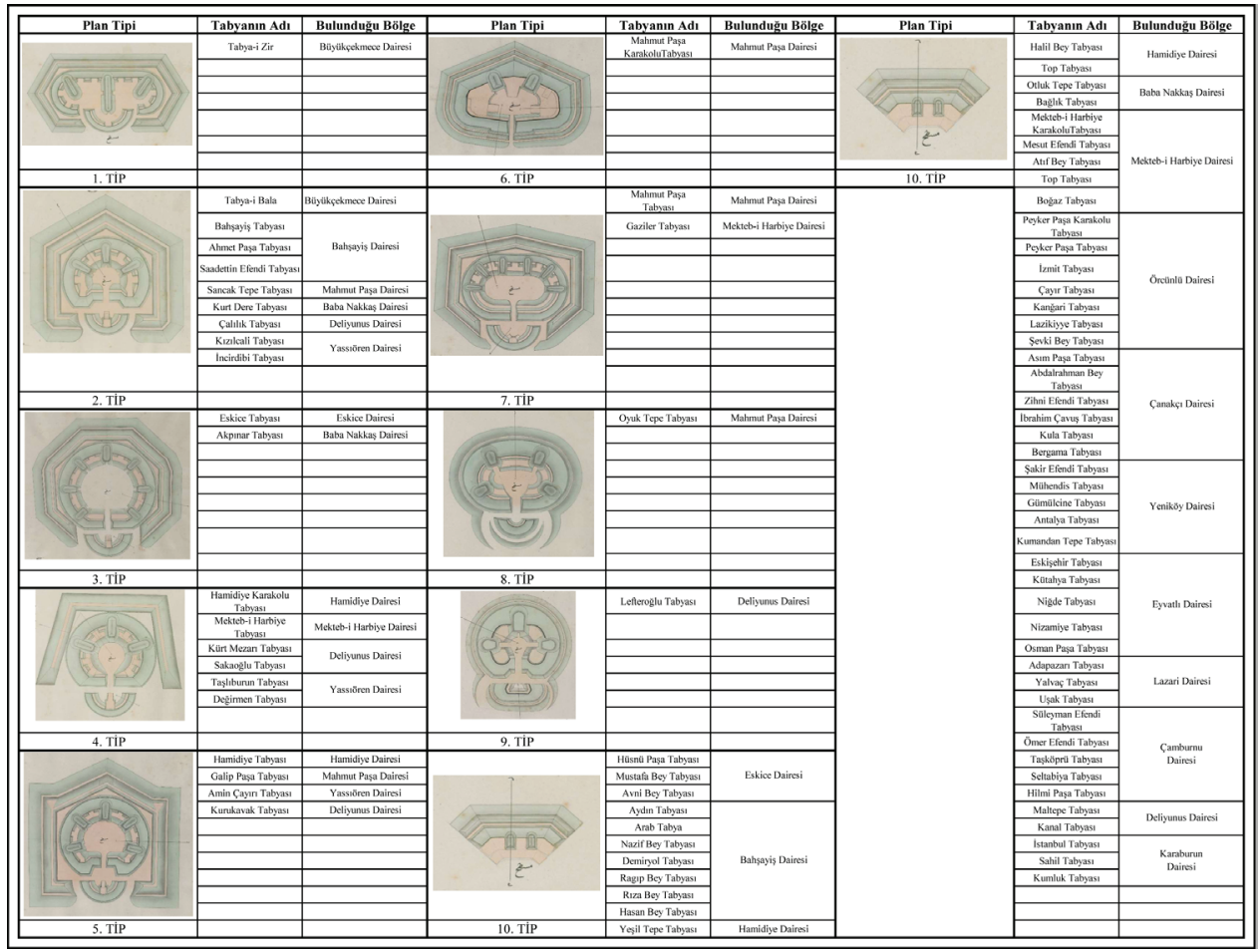

Şekil 20: Çatalca Savunma Hattı'da inşa edilmiş tabyaların planları (NEK, 93178).

1878'de Ferik Bekir Paşa tarafından hazırlanan raporda 28 tabya bulunurken, Çatalca İstihkâmatı İnşa Komisyonu'nun düzenlediği 1880 tarihli belgede tabya sayısının 83'e çıkmış olması, Çatalca Savunma Hattı'nın İstanbul'un savunulmasındaki önemini yansıtmaktadır. Ayrıca, birçok arşiv belgesinde bu savunma hattına gösterilen önem açıkça okunmaktadır. 25 Ekim 1912 tarihli Osmanlı Arşivi belgesinde, savunma hattı için gerekli olan askeri teçhizatın ve yapı malzemelerinin bir an önce bölgeye ulaştırılması, 16 Kasım 1912 tarihli belgede ise Çatalca Hattı'nın sağlamlaştırılarak herhangi bir saldırıda geçilemeyecek hale getirilmesi gerektiği yazmaktadır. ${ }^{59}$ Bölgedeki savunma yapılarının bakım ve onarımına özen gösteren Osmanlı, ordunun geri hizmetlerine de dikkat etmiştir. ${ }^{60}$ Topçu Kaymakamı Yakup Vasfi Bey, raporunda, savunma hattındaki personele daha fazla erzak gönderilmesi gerektiğini belirtmiştir. ${ }^{61} 11$ Kasım 1912 tarihli belgede de ordunun iaşesi için İstanbul firınlarından günlük yüz bin kilo ekmeğin, Harbiye Nezareti'nden de peksimet ve et ihtiyacının sağlandığına dair karar alındığ 1 yazmaktadır. ${ }^{62}$

59 BOA, BEO., 4140-310484; MV., 171-15.

60 Uzdil, 2006, 7.

61 BOA, Y..MTV., 49-9.

62 BOA, MV., 171-1. 
Greene, Çatalca'daki savunma hattından söz ederek, dünyanın hiçbir başkentinde böyle bir hattın olmadığını ve bu hattın, tamamlanması durumunda sayıca üstün düşman ordularını zor durumda bırakacak coğrafi özelliklere sahip olduğunu belirtmiştir. ${ }^{63}$ Savunma hattıyla ilgili bir başka açıklamayı da Lev Troçki yapmış ve Balkan Savaşları sırasında Bulgar bir politikacının kendisine, Çatalca Savunma Hattı'nı yarma ihtimalinin stratejik bir ütopya olduğunu söylediğini aktarmıştır. ${ }^{64}$

Çatalca Bölgesi'ndeki savunma hattı Balkan Savaşları'nın sonuna kadar çeşitli müdahalelerle güçlendirilmeye çalışılmıştır. Yaklaşık 35 yıl boyunca mevcut savunma yapılarının bakım ve onarımları yapılmış ve yeni savunma yapıları inşa edilmiştir. Süreç içerisinde savunma yapılarının dışında, yüz yataklı ahşap hastane binası, un değirmenleri ve erzak ambarları gibi farklı işlevlere sahip yapılar inşa edilerek savunma hattı güçlendirilmeye, görevli personelin ihtiyaçları hızlı bir şekilde karşılanmaya çalışılmıştır.

Çatalca Savunma Hattı'ndaki tabyalar, siperlerden, mühimmat depolarından ve top atışlarının gerçekleştiği düz platformlardan - banketlerden oluşmaktadır. Savunma hattında görevli askerler çadırlarda ve ahşap barakalarda barındırıldığı için tabyalarda koğuş ya da mutfak vb. servis mekânları bulunmamaktadır. Tabyalar topoğrafyaya uyumlu bir şekilde inşa edilmiş olup arazi eğimine göre tabyaların plan şemaları değişmektedir. Bölgedeki tepelerin en yüksek noktasinda bulunan tabyalar poligonal ya da dairesel plan şemasına sahipken arazi eğiminin azaldığı yerlerde doğrusal çözümlemeler yapılmıştır. Bölgedeki tabyalar plan düzenine bağlı olmaksızın, tabya merkezinden çepere doğru kesit düzleminde "Parapet, "Hendek" ve "Sahra Şevi" sıralamasına göre düzenlenmiştir. Bu sisteme göre parapet bölümünde, mühimmat depoları ve depoların arasinda da top atışlarının gerçekleştirildiği banketler yer almaktadır.

Savunma hattındaki yapıların inşasında, taş, tuğla ve ahşap yapı malzemeleri kullanılmıştır. 1912 tarihli ATASE arşivi belgesinde, Çatalca Savunma

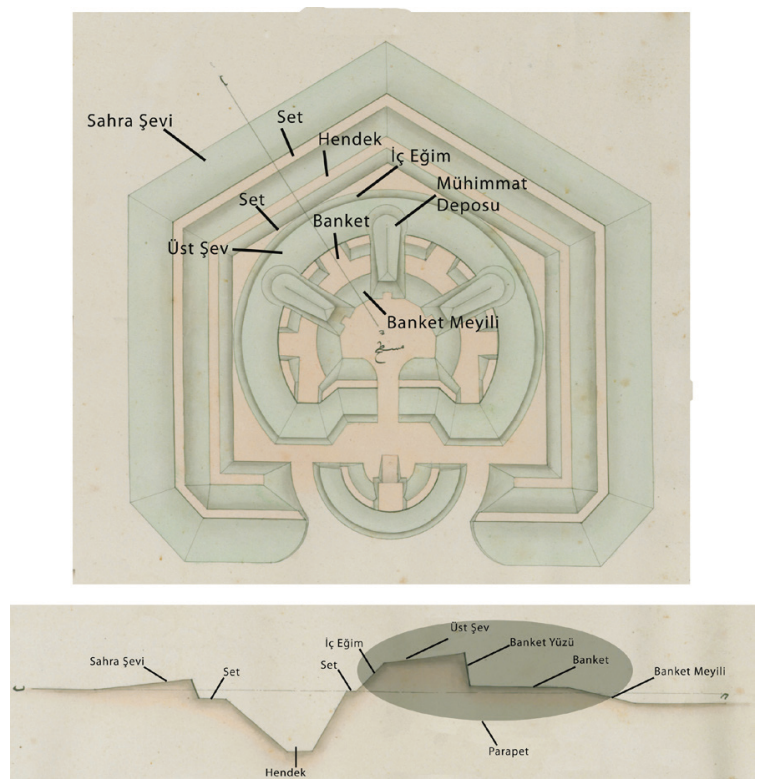

Şekil 21: Çatalca Savunma Hattı'da inşa edilmiş bir tabyanın (Ahmet Paşa Tabyasi) plan ve kesiti (NEK, 93178).

63 Greene, 1879, 427.

64 Troçki, 2012, 230. 
Hattı'nda inşa edilmekte olan yapılar için Ispartakule'den ve Karadeniz Boğazı'ndan taş getirtildiği belirtilmiştir. ${ }^{65}$ Ayrıca savunma hattının birçok yapısında da İstanbul'dan getirilen damgalı tuğlalar kullanılmıştır. Savunma hattında günümüze ulaşan tüm mühimmat depoları, toprağa gömülü olacak şekilde yığma kâgir duvarlara sahiptir. Tek hacimli ve 15-20 $\mathrm{m}^{2}$ 'lik bir alana sahip bu depoların zemin döşemeleri taş, tavanları ise tuğla tonozdur. 70-80 cm kalınlığındaki duvarlar ise kireç harcı kullanılarak kaba yonu ya da moloz taşlarla örülmüştür.
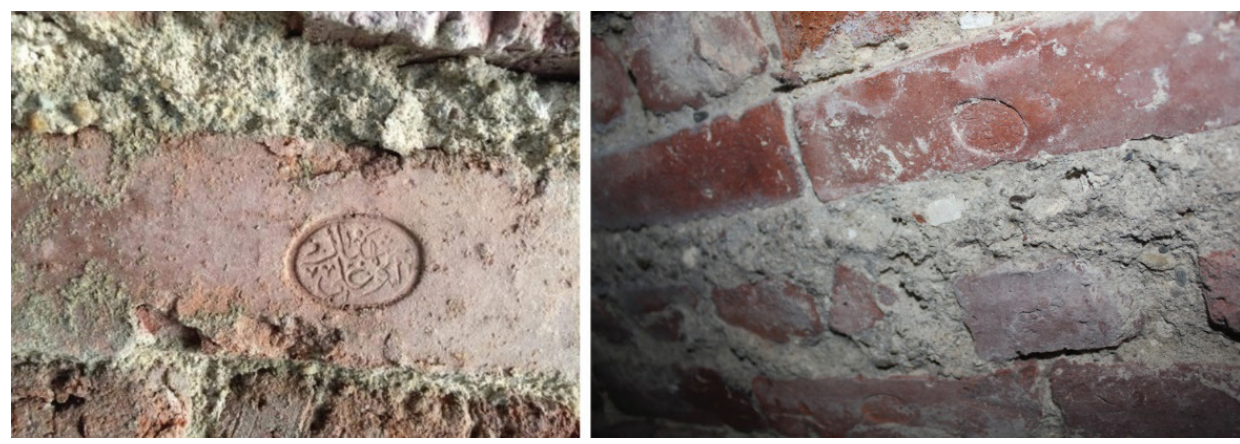

Şekil 22: "Şahbazoğlu" damgalı tuğlalar. ${ }^{66}$

Savunma hattını, güney, merkez ve kuzey olmak üzere üç bölgeye ayıran Aksun, hattın güneyinde, Büyükçekmece Gölü’ne yakın yerlerde, yaz aylarında dahi kurumayan bataklıkların düşman ordularının hareketini kısıtladığını, kuzeyde ormanlık alanların ve dar vadilerin düşman askerlerinin savunma hattına girmesini kolaylaştırdığını ancak bölgedeki mevzilerin dik tepelerde oluşunun savunma birlikleri için olumlu bir durum olduğunu belirtmiştir. ${ }^{67}$ Ayrıca, kuzey ve güney bölgelerinin arasındaki bölgenin geniş ovalara sahip olması ve savunma hattını yarmak isteyen düşman birliklerinin açıkta ve korunaksız bir şekilde saldırıya geçecek olmaları savunma birlikleri açısından önemli bir avantaja dönüşmektedir.

Büyükçekmece Gölü’nün doğu kıyısında başlayan bu savunma hattı, Nakkaş Mahallesi'ne kadar tek hat olacak şekilde kuzeye doğru uzanır. Nakkaş Mahallesi'nden sonra doğu ve batı kollarına ayrılarak farklı iki doğrultu oluşturur. Doğu kolu üzerindeki savunma yapıları Karadeniz Kıyısındaki Karaburun'da, batı kolundaki yapılar ise Terkos Gölü’nün güney kıyısında Yazlık Mahallesinde sonlanır. Nakkaş Mahallesi'ne kadar savunma hattında güneyden kuzeye doğru, Büyükçekmece, Eskice, Bahşayiş, Hamidiye, Mahmut Paşa ve Baba Nakkaş daireleri bulunur. Nakkaş’tan sonra ise, doğu kolunda, Yassı̈ren, Deliyunus ve Karaburun, batı kolunda da Mektebi Harbiye, Örcünlü, Çanakça, Yeniköy, Eyvatl1, Lazari ve Çamburnu daireleri bulunur.

65 BLH-185-11-4.

66 "Şahbaz Tuğla Fabrikası" 1882 yılında Şahbaz Agiya tarafından Haliç kıyısında kurulmuştur.

67 Aksun, 1930, 494-495. 

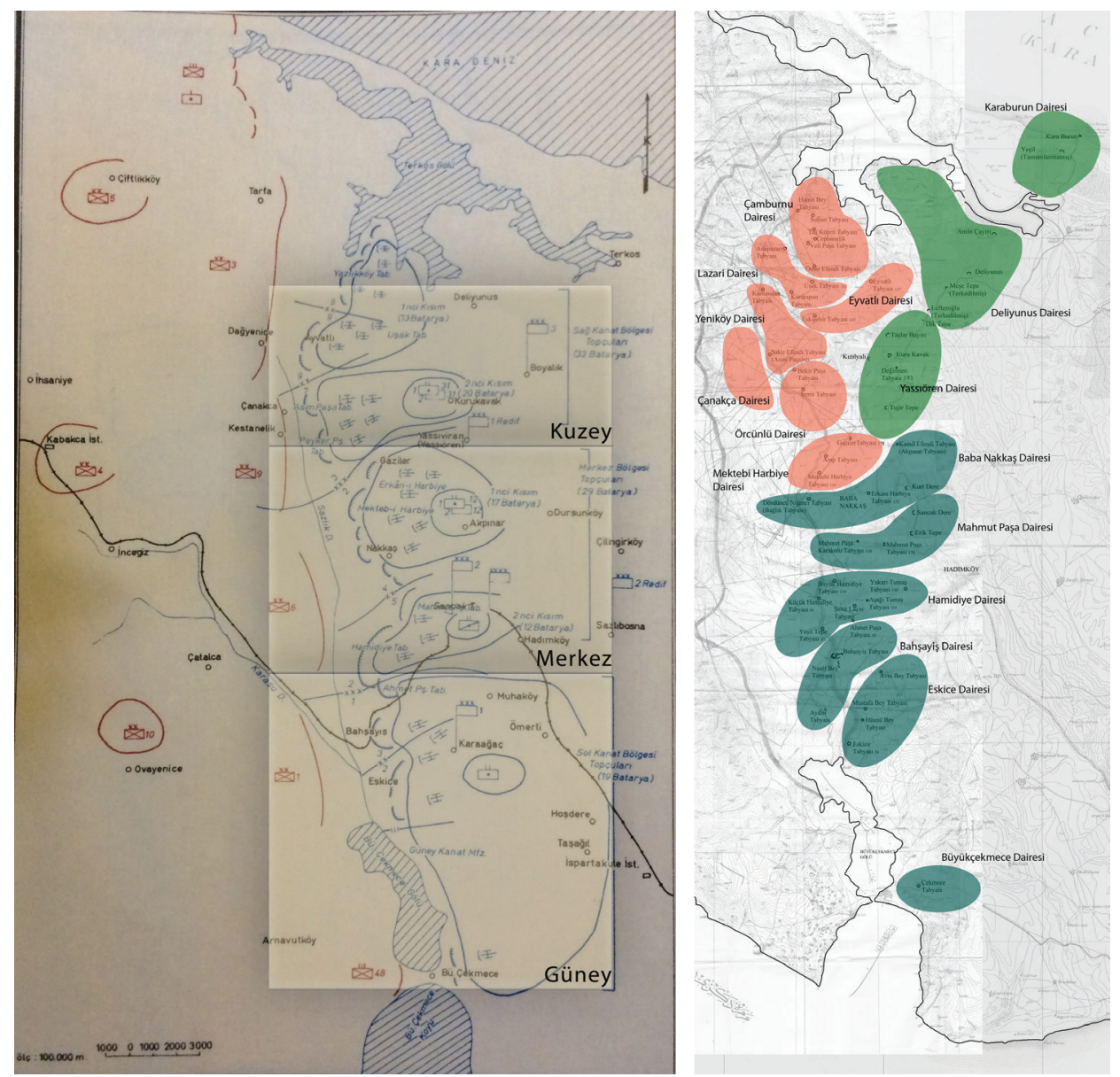

Şekil 23: Çatalca Savunma Hattı'ndaki tabyaların bulunduğu bölgeler (Uzdil, 2006).

Çatalca Savunma Hattı'na ait tabyaların büyük bir kısmı günümüze ulaşamamıştır. Sadece altı tabyaya ait kâgir mühimmat depoları ve bu tabyaların arazi üzerindeki plan izleri günümüzde varlığını sürdürmektedir.

\section{Eskice Tabyası:}

Büyükçekmece gölünün kuzey kıyısında hâkim bir tepe üzerinde yer alan Eskice Tabyası günümüzde, Büyükçekmece ilçesi, Eskice mahallesi 6069 nolu parselde bulunmaktadır. 1878 tarihli arşiv belgesinde "Onarılan Tabyalar" arasında yer alan bu tabyanın, 1877-78 Osmanlı - Rus Savaşı önlemleri kapsamında inşa edildiği anlaşılmaktadır. Özgün plan şemasında, sekizgen bir hendek ve dairesel bir parapet yapısına 

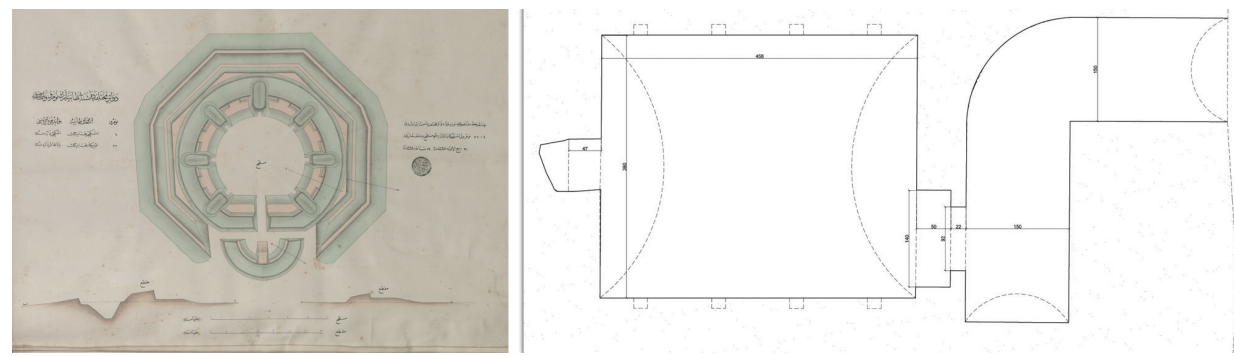

Şekil 24: Solda; Eskice Tabyası vaziyet planı (NEK, 93178), sağda; tabyanın mevcut krokisi.

(M. Efeoğlu, 2019)
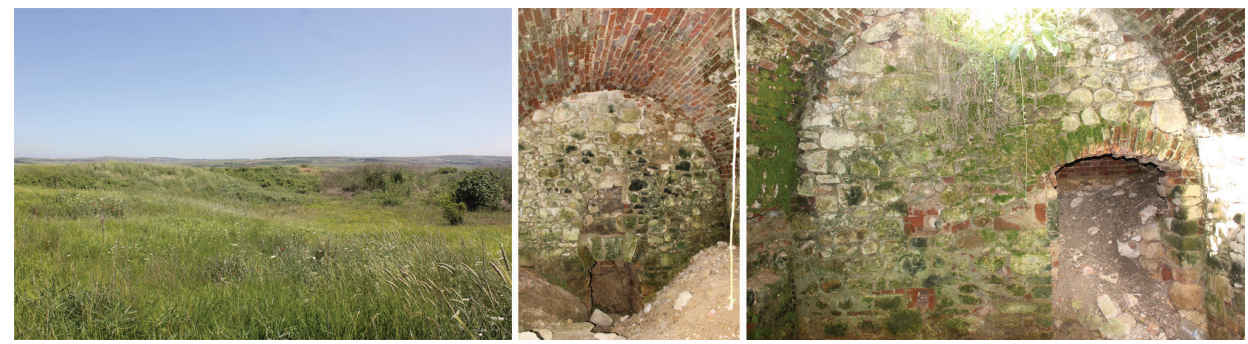

Şekil 25: Eskice Tabyası. (M. Efeoğlu, 2019)

sahip tabyanın, yedi mekânı bulunmaktadır. Ancak, bu tabyaya ait mekânlardan yalnızca bir tanesi günümüze ulaşmıştır. Tamamı toprağa gömülü bu yapı, 1,5 m genişliğinde -Lşeklinde bir giriş koridoruna ve 4x4,5 m boyutlarında dikdörtgen bir iç hacme sahiptir. Mekânın giriş kapısının karşısına denk gelen duvarda $45 \times 75 \mathrm{~cm}$ boyutlarında bir niş ve yan duvarlarda ise $1 \mathrm{~m}$ arayla, $40 \mathrm{~cm}$ derinliğinde, $15 \times 30 \mathrm{~cm}$ ölçülerinde yatayda iki sıra olacak şekilde küçük nişler bulunmaktadır. Zemin seviyesinde ve zeminden 40 cm yukarıda bulunan bu nişlerin, yapıya isabet edecek topların oluşturacağı basıncı ve tahribatı azaltmak için bırakıldıkları düşünülmektedir. Mekânın duvarları moloz taş örgülü, üst örtüsü ise tuğla tonozdur.

\section{Arab Tabya:}

Çatalca ilçesinin Bahşayiş mahallesinde 440 nolu parselde bulunan tabya, Eskice Tabyası'nın yaklaşık 4 km kuzeyinde yer almaktadır. Osmanlı - Rus Savaşı'ndan sonra, Çatalca İstihkâmatı İnşa Komisyonu'nun 1880 tarihli belgelerinde ismi geçen bu yapı, arazi eğiminin az olduğu bir bölgede inşa edilmiştir. Birbirine düz koridorlarla bağlı on mekândan oluşan Arab Tabya, vaziyet planı açısından, günümüze ulaşan tabyalar arasında, yayvan bir yapıya sahiptir. Ancak, alanda yapılan belgeleme çalışmalarında, yapının özgün plan çiziminden görece farklı olduğu ve günümüze dokuz mekânının ulaştığ 1 tespit edilmiştir. Moloz taş duvarlara ve tuğla tonozlu üst örtüye sahip yapının koridorları ve bu koridorlara dik bir şekilde bağlanan $25 \mathrm{~m}^{2}$ 'lik dikdörtgen hacimli mekânları, 2,5 m genişliğinde ve 3 m yüksekliğindedir. 


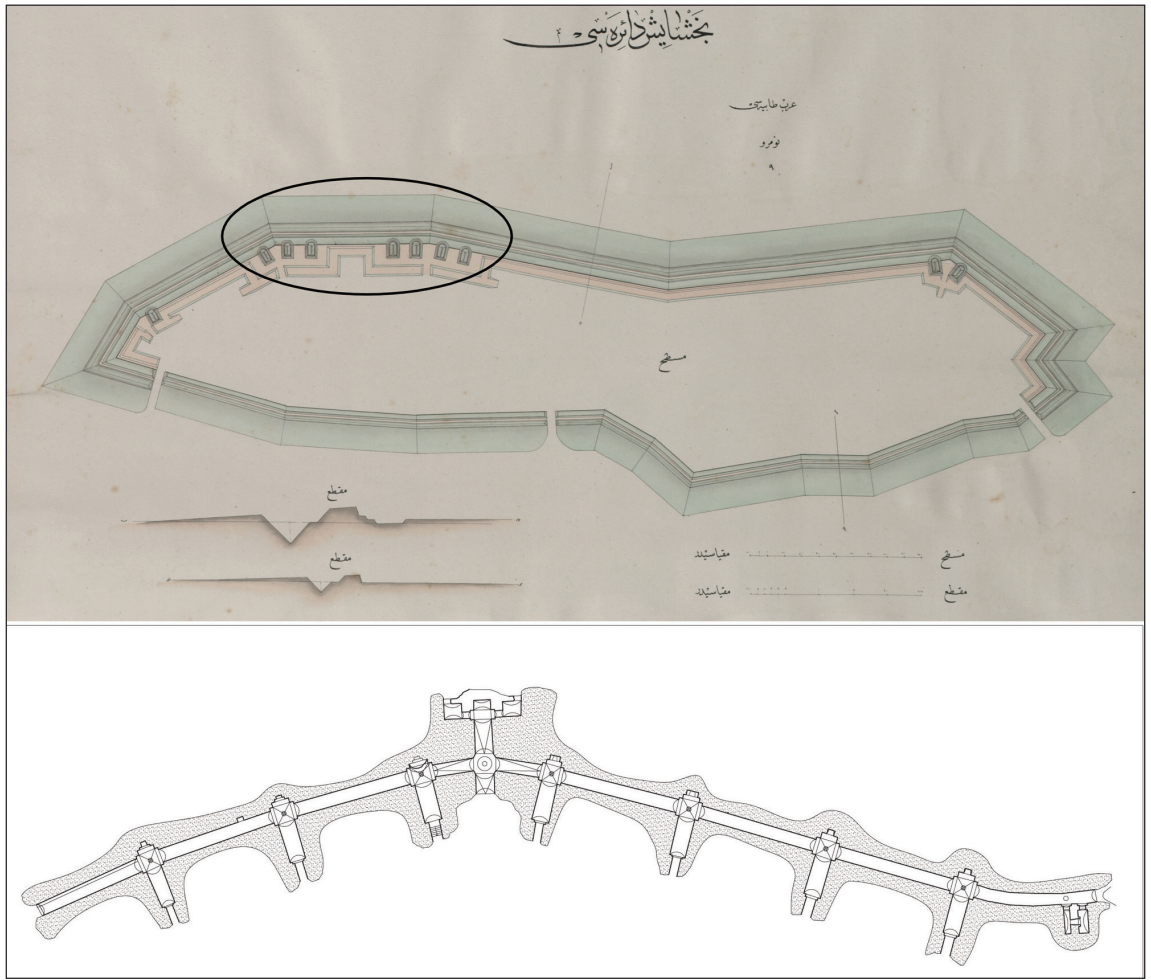

Şekil 26: Üstte; Arab Tabya vaziyet planı (NEK, 93178), altta; tabyanın mevcut krokisi. (M. Efeoğlu, 2019)
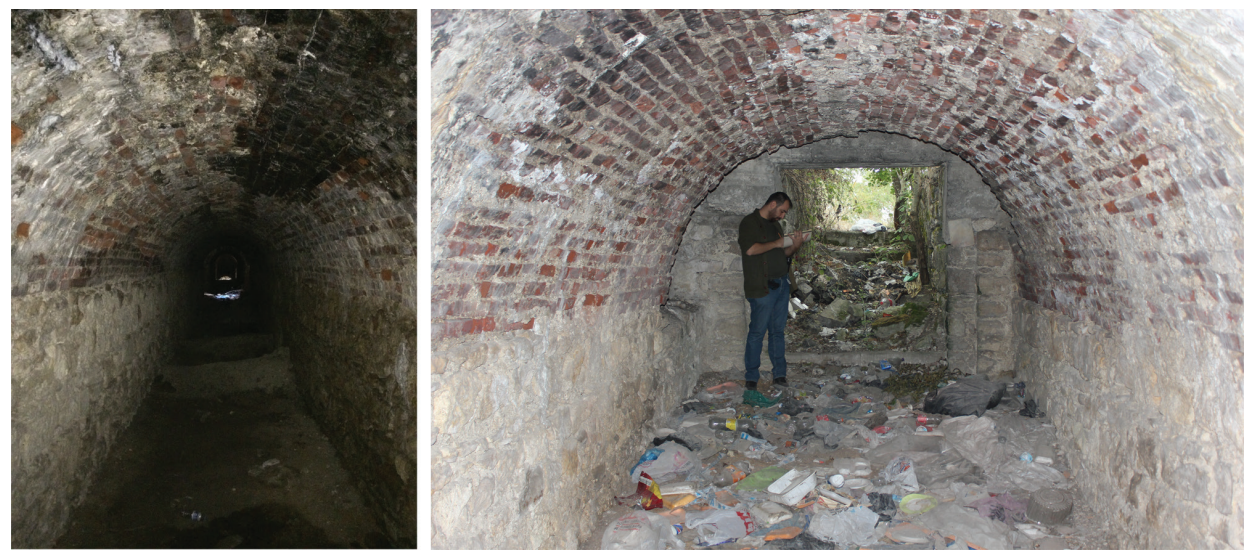

Şekil 27: Arab Tabya, iç mekan görüntüleri. (M. Efeoğlu, 2019) 


\section{Ahmet Paşa Tabyası:}

Arab Tabya'nın yaklaşık 2 km kuzey doğusunda yer alan Ahmet Paşa Tabyası, Bahşayiş mahallesinin 224 nolu parselinde bulunmaktadır. Osmanlı - Rus Savaşı önlemleri kapsamında inşa edilen ilk tabyalar arasında yer alan yapı, özgün plan çiziminde, beşgen bir hendeğe ve üç mekâna sahiptir. Ancak, günümüzde özgün plan şemasını kaybetmiş tabyada yalnızca bir mekân varlığını sürdürmektedir. 3,5 m uzunluğunda eğimli bir girişe ve $18 \mathrm{~m}^{2}$ 'lik bir iç hacme sahip mekânın zemin seviyesi ile dış mekân arasında 2 m'lik kot farkı bulunmaktadır. Moloz taş duvarlara ve tuğla tonozlu üst örtüye sahip yapının tavanında $50 \mathrm{~cm}$ çapında ve $3 \mathrm{~m}$ uzunluğunda bir havalandırma bacası mevcuttur.
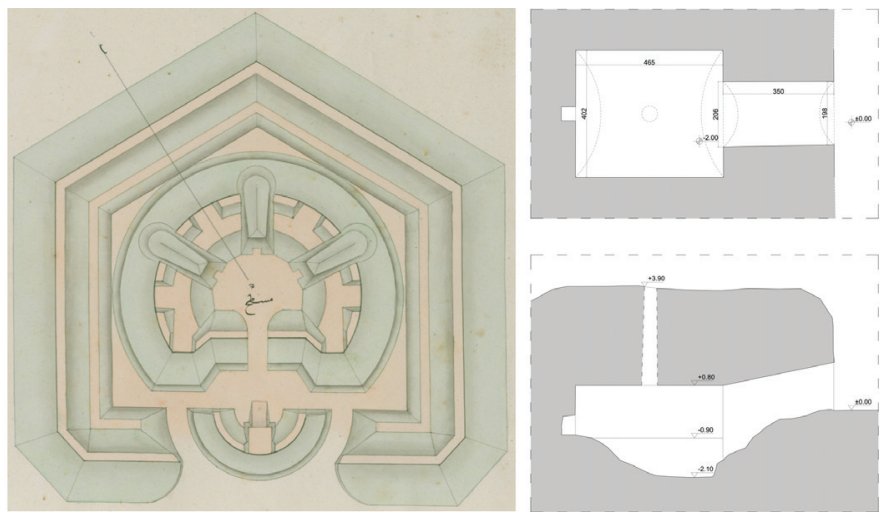

\section{Şekil 28:}

Solda; Ahmet Paşa Tabyası vaziyet planı (NEK, 93178), sağda; tabyanin mevcut plan ve kesit krokisi.

(M. Efeoğlu, 2019)
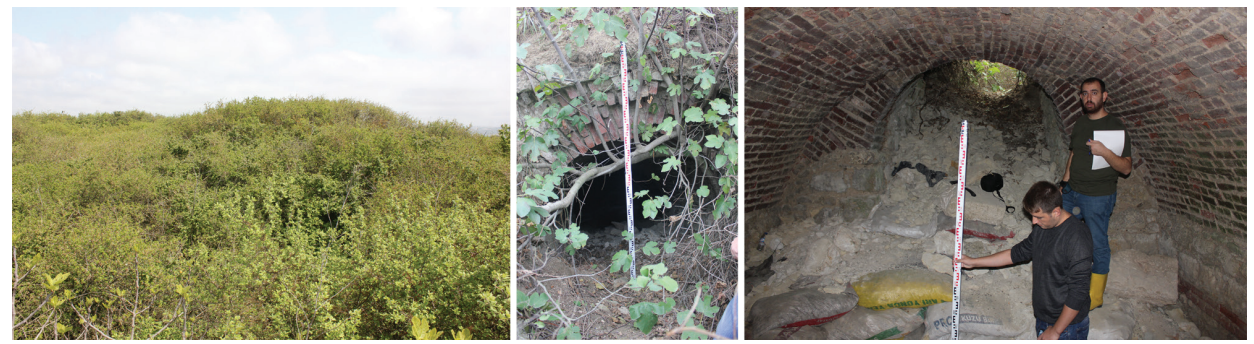

Şekil 29: Ahmet Paşa Tabyası. (M. Efeoğlu, 2019)

\section{Hamidiye Tabyası:}

Ahmet Paşa Tabyası'nın yaklaşık 1,5 km kuzey batısında bulunan tabya, Bahşayiş mahallesinde 1537 nolu parselde bulunmaktadır. Ferik Bekir Paşa'nın 1878'de hazırlamış olduğu raporda "Yeni İnşa Edilen Tabyalar" arasında ismi geçen yapı, Osmanlı - Rus Savaşı'ndan kısa süre sonra inşa edilmiştir. Özgün plan çiziminde üç kenarlı bir hendek düzenine sahip tabyanın, dairesel bir şemaya ve üç mekâna sahip olduğu anlaşılmaktadır. 
Günümüzde tarım arazisinin içinde kalan tabyanın bir mekânı dışında, herhangi bir yapısı mevcut değildir. 1,5 m genişliğe sahip -L- biçimindeki giriş koridorundan sonra $20 \mathrm{~m}^{2}{ }^{\prime}$ lik bir iç hacme sahip yapının, duvarları moloz taş, üst örtüsü ise tuğla tonozdur. İç mekânın duvarlarında, hem zemin seviyesinde, hem de zeminden $40 \mathrm{~cm}$ yukarıda olacak şekilde, $15 \times 30 \mathrm{~cm}$ ölçülerinde ve $40 \mathrm{~cm}$ derinliğinde, birer metre mesafelerle küçük nişler, girişin karşısındaki duvarda ise $50 \times 75 \mathrm{~cm}$ boyutlarında daha büyük bir niş bulunmaktadır.
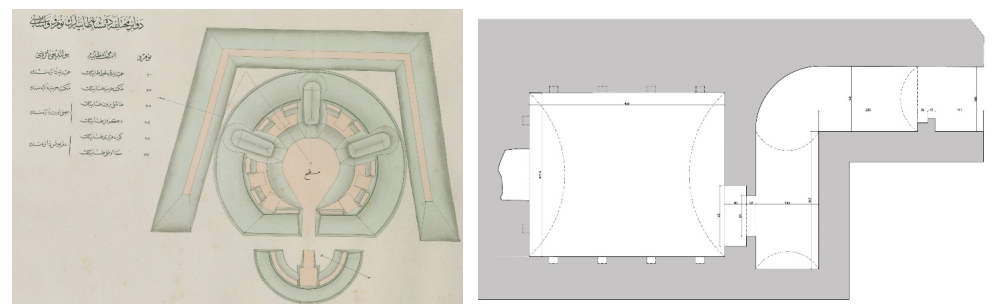

Şekil 30: Solda; Hamidiye Tabyası vaziyet planı (NEK, 93178), sağda; tabyanın mevcut krokisi.

(M. Efeoğlu, 2019)
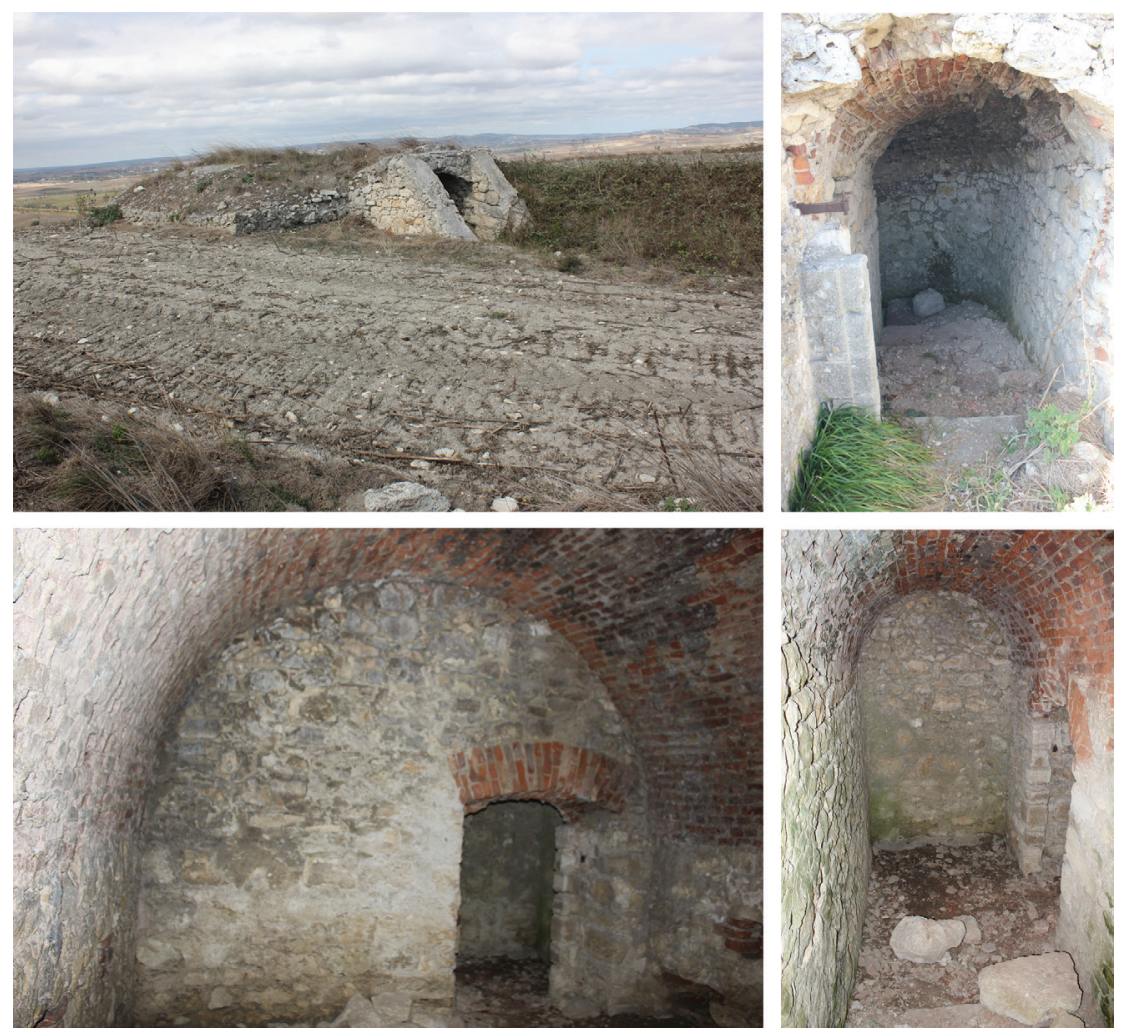

Şekil 31: Hamidiye Tabyası. (M. Efeoğlu, 2019) 


\section{Mahmut Paşa Karakol Tabyası:}

Çatalca Savunma Hattı'nda Osmanlı - Rus Savaşı önlemleri kapsamında inşa edilmiş ilk tabyalardandır. Hamidiye Tabyası'nın 2,5 km kuzey doğusunda yer alan yapı, Çatalca ilçesi, Nakkaş mahallesi, 2008 nolu parselde bulunmaktadır. Yapının özgün vaziyet planı çiziminden beşgen bir yapıya ve iki mekâna sahip olduğu anlaşılmaktadır. Günümüzde tarım arazisi içinde kalan tabyanın, özgün plan şeması kaybolmuş olmasına rağmen iki mekânı da varlığını sürdürmektedir. Ortak iç ölçülere ve yapı malzemesine sahip mekânların zemin kotu ile dış mekân arasında 2 m'lik kot farkı vardır. Moloz taş duvarlara ve tuğla tonozlu üst örtüye sahip mekânların tavanlarında, $50 \mathrm{~cm}$ çapında ve 3 m uzunluğunda birer havalandırma bacası bulunmaktadır.

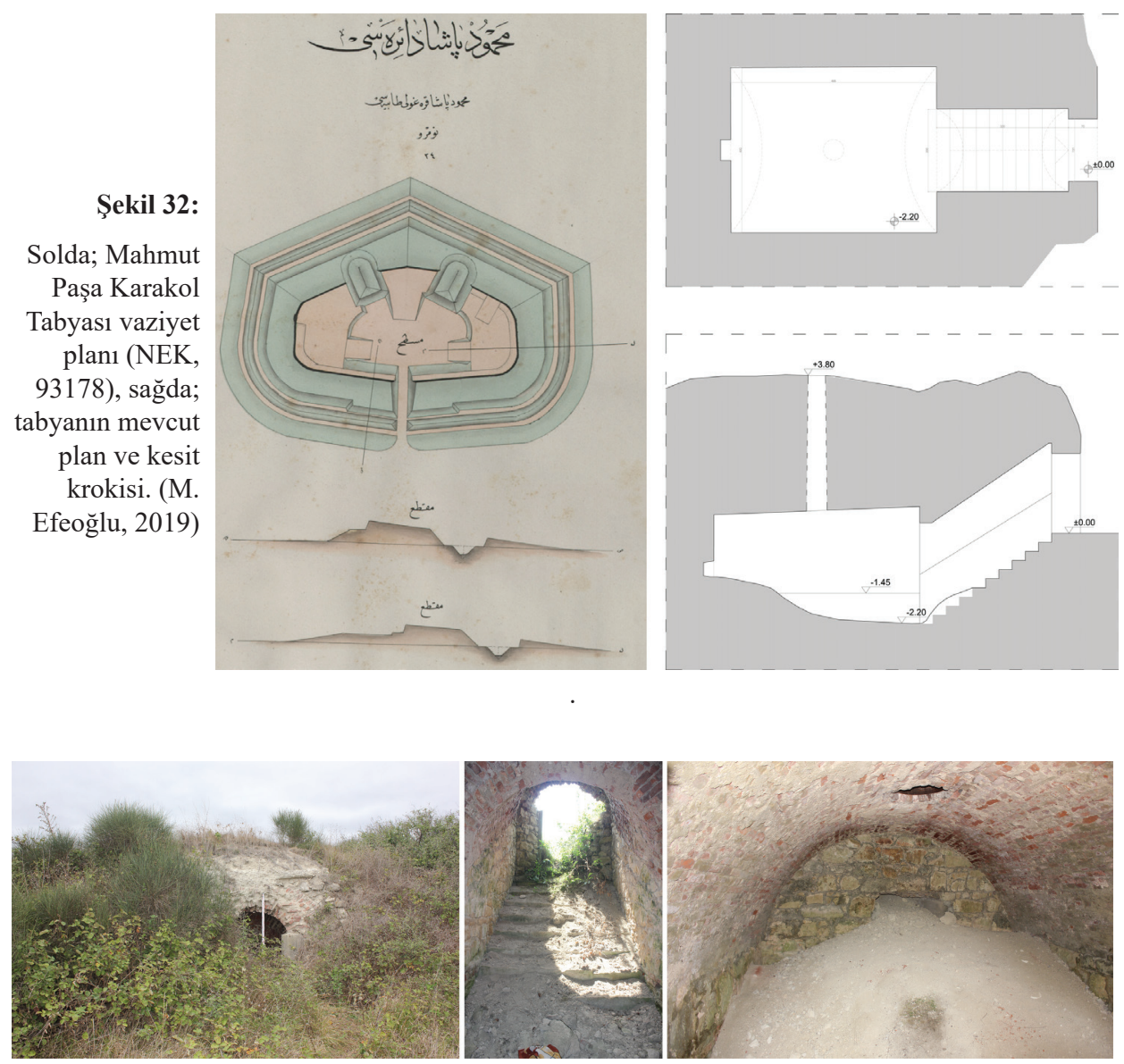

Şekil 33: Mahmut Paşa Karakolu Tabyası. (M. Efeoğlu, 2019) 


\section{Mekteb-i Harbiye Tabyası:}

Mahmut Paşa Karakolu Tabyası'nın 3,5 km kuzey batisinda bulunan tabya, Nakkaş mahallesinde, 2787 ve 2774 nolu parsellerin arasındaki tepelik alanda yer almaktadır. Hamidiye Tabyası ile ortak plan şemasına sahip yapı, 1877-78 Osmanlı - Rus Savaşı önlemleri kapsamında inşa edilmiştir. Günümüzde özgün vaziyet planı düzeninin tamamına yakınını kaybetmiş olan yapının yalnızca bir mekânı varlığını sürdürmektedir. 1,5 m genişliğe sahip -L- biçimindeki giriş koridorundan sonra ana mekâna geçilmektedir. $\mathrm{Bu}$ tabyada da Eskice ve Hamidiye tabyalarında olduğu gibi, duvarların hem zemin seviyesinde, hem de 0zeminden 40 cm yükseklikte $15 \times 30$ cm ölçülerinde, birer metre arayla konumlandırılmış nişler ve girişin karşısına denk gelen duvarda ise $50 \mathrm{~cm}$ genişliğinde daha büyük bir niş bulunmaktadır.
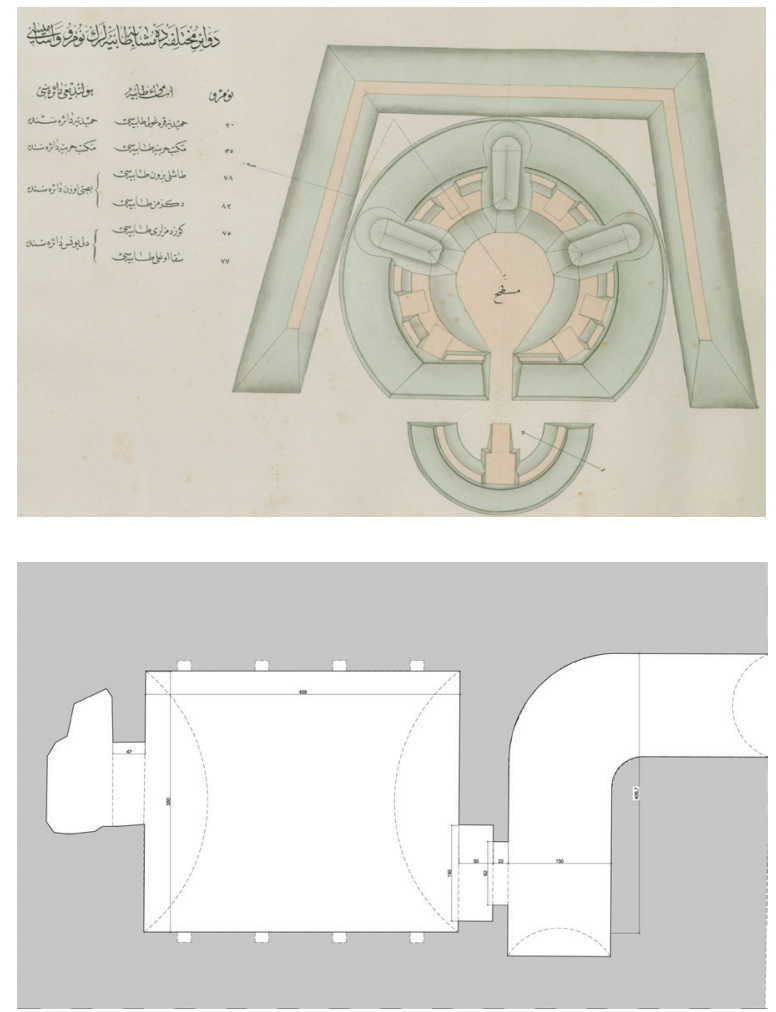

Şekil 34: Üstte: Mekteb-i Harbiye Tabyası vaziyet planı (NEK, 93178). Altta: tabyanın mevcut krokisi.

(M. Efeoğlu, 2019)

Moloz taş duvarlara ve tuğla tonozlu üst örtüye sahip mekân $20 \mathrm{~m}^{2}$ 'dir.
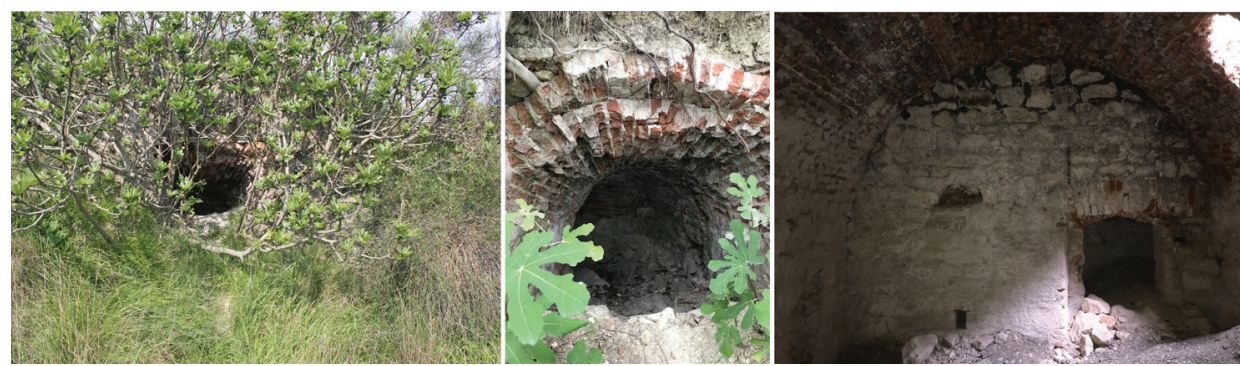

Şekil 35: Mekteb-i Harbiye Tabyası. (M. Efeoğlu, 2019) 


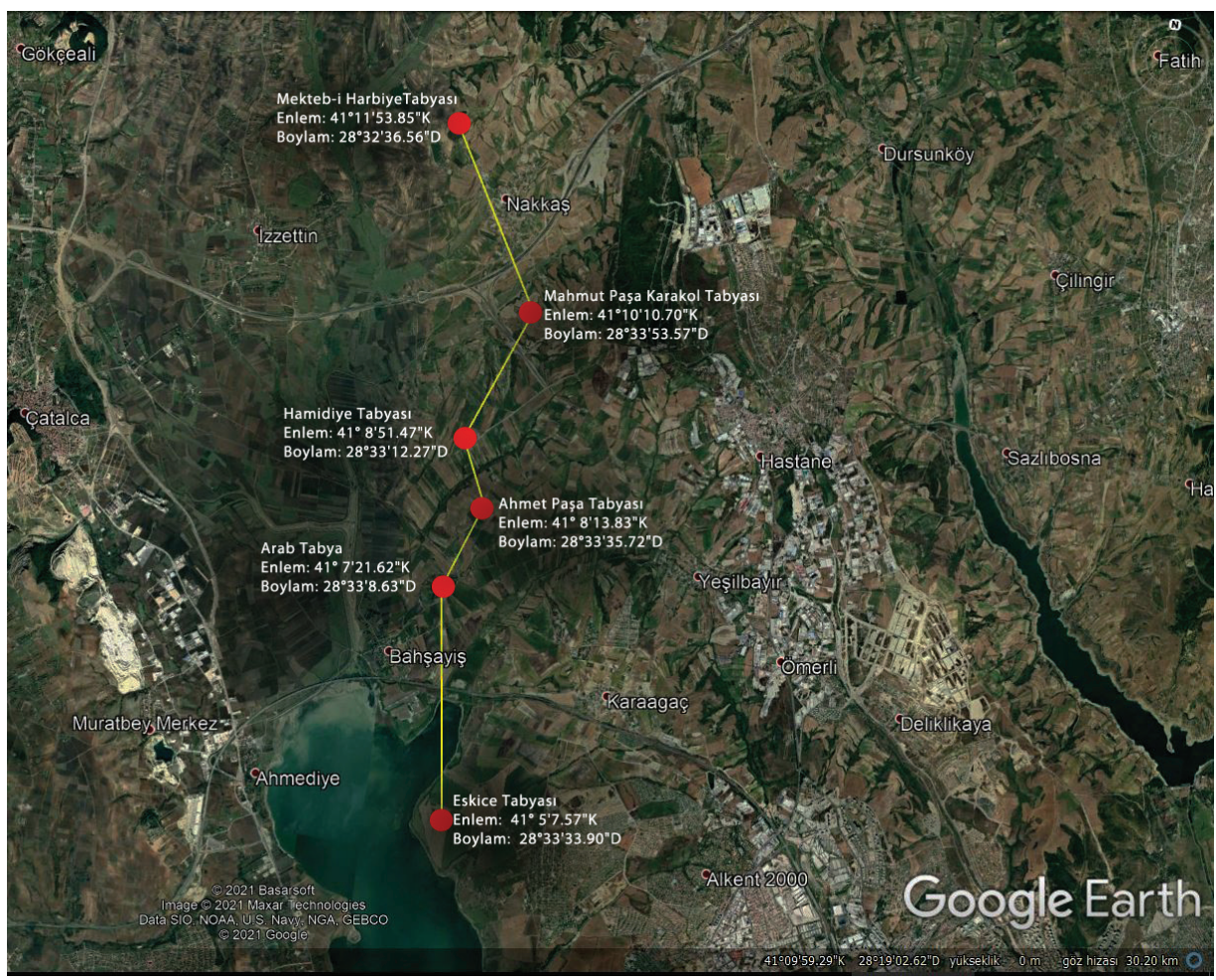

Şekil 36: Çatalca Bölgesi’nde günümüze ulaşan tabyaların konumları.

\subsection{Koruganlar ve Yardımcı Yapılar}

Almanya'nın 1 Eylül 1939'da Polonya'yı işgal etmesinden iki gün sonra Fransa ve İngiltere'nin de Almanya'ya karşı savaş ilan etmesi II. Dünya Savaşı'nın başlamasına neden olmuştur. Neredeyse tüm dünya ülkelerinin dâhil olduğu savaş, uzun yıllar boyunca birçok devleti siyasi ve ekonomik açıdan etkilemiştir. ${ }^{68} \mathrm{Bu}$ dönemde, Türk dış politikasının amacı, savaşa girmeden Türkiye Cumhuriyeti'nin toprak bütünlüğünü korumak, devleti siyasi ve ekonomik bir krizin içine sokmamak olmuştur. ${ }^{69}$ Dönemin Cumhurbaşkanı İsmet İnönü, her ne pahasına olursa olsun ülkeyi savaştan uzak tutma politikası izlemiş ve Türkiye'nin bu savaşa girmesini istememiştir. ${ }^{70}$ Gürün, batılı devletlerin baskısına rağmen, ülkenin savaş dışında tutulmuş olmasını dış politikanın başarısına dayandırmaktadır. ${ }^{71}$

68 Hart, 2009, 40, 998.

69 Weisband, $2000,7$.

70 Tuncer, 2012, 37-38.

71 Gürün, 1988, 1468. 
Türkiye, II. Dünya Savaşı'na katılmamış olsa da dış dünyada yaşanan olaylar sonucu ülke güvenliğini tehlikeye sokacak tehditlere karşı her an savaşa girecekmiş gibi çeşitli önlemler almıştır. İtalya'nın 7 Nisan 1939'da Arnavutluk'u işgal etmesi dönemin hükümetini tedirgin etmiş ve alınması gereken önlemler hızlandırılmıştır. ${ }^{72}$ Alınan önlemler çerçevesinde, 1938 yılına kadar kadroları az olan ordu müfettişlikleri ordu komutanlıklarına dönüştürülmüş ve asker sayıları artırılmıştır. ${ }^{73}$ Trakya'nın ve İstanbul'un boşaltılması gündeme gelmiş, İstanbul'daki birçok kamu kuruluşu farklı illere taşınmıştır. ${ }^{74}$ Ülke güvenliğini sağlamak adına bu dönemde Avrupa'nın birçok yerinde inşa edilen ve dönemin silah teknolojisine uygun olan betonarme savunma yapıları yurdun stratejik açıdan önemli yerlerine inşa edilmiştir. Ordunun yeteri kadar tank, zırhlı araç ve uçağının olmaması, Trakya üzerinden gerçekleşecek bir saldırıda, ordunun savunma savaşı yapmasını ve sağlam savunma hatlarına sahip olmasını gerekli kılmıştır. ${ }^{75}$ Bu kapsamda, 3 Ekim 1939'da çıkarılan bir kararnameyle "Çakmak Hattı" olarak adlandırılan savunma hattının yapımına karar verilmiş̧ir. ${ }^{76}$ Hattın hızlı bir şekilde tamamlanması için Milli Müdafaa ve Maliye Vekilliği’nin teklifi üzerine inşaat işlerinin özel firmalara ihale edilmesi ve inşaat işlerinde acemi askerlerin de çalışıırılması kararlaştırılmıştır. ${ }^{77}$ Yapımı için çok sayıda işçinin ve askerin çalıştığ 1 Çakmak Hattı'nda, ülkedeki çimento ve demir olanaklarının neredeyse tamamı kullanılmışıır. ${ }^{78} 9$ Mart 1940 tarihli Cumhuriyet Arşivi belgesinde, Çakmak Hattı'nın yapımı için ödenmesi planlanan 7.301 .742 liranın belirli aralıklarla ödeneceği, ilk ödemenin de nisan ayı içinde 2.301.742 lira olarak yapılacağ belirtilmiştir. ${ }^{79}$ Savunma hattına ait toplam 47.000 $\mathrm{m}^{3}$ 'lük on farklı tipte yapılması istenen 83 betonarme koruganın, $30.000 \mathrm{~m}^{3}$ 'lük tank mani hattının ${ }^{80}$ ve $500.000 \mathrm{~m}^{3}$ 'lük kazı işinin Nafia Vekâleti'nin tavsiye ettiği mühendis gruplarına verilmesi, inşaat işlerini yapacak teknik ekibin giderlerinin Nafia Vekâleti'nce, çalıştırılacak memur ve mühendislerin maaşlarının ise Milli Müdafaa Vekâleti tarafindan ödenmesi için karar çıkarılmak istenmiştir. ${ }^{81} 20$ Temmuz 1940 tarihli, Milli Müdafaa Vekâleti'nin Maliye'ye gönderdiği resmi yazıda üç inşaat şirketinin ve altı müteahhidin ismi geçmektedir. ${ }^{82}$ Ancak, yapılması istenen işler, isimleri verilen şirketlerden ve müteahhitlerden eksiltme yapılarak, 23 Temmuz 1940'da çıkarılan kararnameyle kabul

72 Armaoğlu, 1958, 142.

73 Tekeli ve İlkin, 2014, 402.

74 Çetin, 2013, 787.

75 Tekeli ve İlkin, 2014, 404.

76 BCA, 88-97-6.

77 BCA, 91-61-4.

78 Tekeli ve İlkin, 2014, 404.

79 BCA, 90-23-2.

80 Avrupa'da "Ejderha Dişi”" olarak bilinen, tankların geçişini engellemek için tasarlanmış betonarme bariyerlerdir.

81 BCA, 92-73-19.

82 BCA, 92-73-19. 
edilmiştir. ${ }^{83}$ Ayrıca, topoğrafya haritalarının çıkarılması, teknik çizimlerin yapılması ve uygulamaların kontrolü için beş aylık yeni bir kadronun oluşturulması 10 Eylül 1940'ta Milli Müdafaa ve Maliye Vekilliği'nin teklifi üzerine İcra Vekilleri Heyetince kabul edilmiştir. ${ }^{84}$ Kısa sürede bitirilmesi hedeflenen inşaat işlerinin tamamlanamaması sonucu, önce 16 Nisan'da daha sonra 10 Temmuz 1941'de savunma hattında çalıştırılmak üzere yeni işçilerin alınması kararlaştırılmıştır. ${ }^{85} 21$ Kasım 1941 tarihinde de Amerika' dan dört bin ton demirin alınması için 350.000 dolar ödenmiştir. ${ }^{86} 1940$ yılında yapımına başlanan Çatalca Bölgesi’ndeki hattın ne zaman tamamlandığı bilgisi net değildir. 27 Mart 1942 tarihli Cumhuriyet Arşivi belgesinde, “...inşa edilmekte olan betonarme koruganlar için zehirli gazlara karşı Kızılay Maske Fabrikası'ndan filtre cihazlarının alınması..." ifadesinden bölgedeki inşaat işlerinin devam ettiği anlaşılmaktadır. ${ }^{87}$
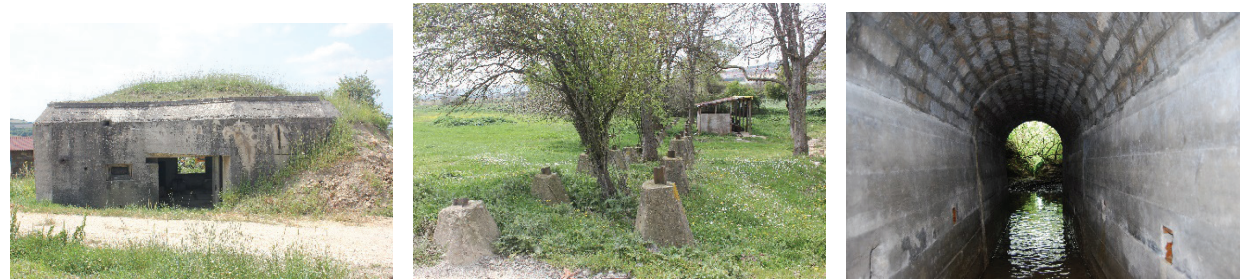

Şekil 37: Çakmak Hattı'na ait bir korugan, tank mani hattı ve yeraltı tüneli (Yazar, 2020).

Arşiv belgelerinde, "Çatalca Müstahkem Mevki” olarak da adlandırılan Büyükçekmece ve Terkos Gölleri arasındaki savunma hattı, farklı plan tiplerine sahip koruganlardan, siperlerden, avcı çukurlarından, tünellerden ve bariyerlerden oluşmaktadır. 20 Temmuz 1940 tarihli arşiv belgesinde savunma hattı için 83 betonarme yapının özel inşaat firmaları ve müteahhitler tarafından yapılması kararlaştırılmış ve kısa süre sonra inşaat işleri başlamıştır. Ancak, hava fotoğraflarından ve güncel uydu görüntülerinden elde edilen verilerle beraber, bölgede yapılan saha çalışmaları sonucunda 100'e yakın betonarme korugan tespit edilmiştir. 21 Eylül 2018 tarihli İstanbul Arkeoloji Müzeleri Müdürlüğü tarafindan hazırlanmış raporda ${ }^{88}$ da bölgede inşası devam eden yeni otoyol güzergâhları üzerinde kalan 63 korugandan 59'unun kaldırıldığı yazmaktadır. Bu veriler 1şığında, II. Dünya Savaşı tedbirleri kapsamında Çatalca Bölgesi'nde 160'a yakın betonarme koruganın inşa edildiği anlaşılmaktadır. Ayrıca, savunma hattında, koruganların tamamına yakınının batısında, başka bir ifadeyle düşman birliklerinin geliş yönünde, bir askerin içine girip ateş edebileceği şekilde düzenlenmiş, büyük bir kısmı da toprağa gömülü betonarme avcı çukurları bulunmaktadır. Koruganların ve avcı çukurlarının dışında,

83 BCA, 92-73-19.

84 BCA, 92-86-3.

85 BCA, 95-59-4.

86 BCA, 93-125-8

87 BCA, 98-25-17.

88 Sayı No: 92207046-160.02.01-E.800464; Konu: Kuzey Marmara Otoyol Projesi. 
Çatalca'nın Dağyenice Mahallesi'nde 426 nolu parselde, önce batı yönüne uzanan daha sonra üç kola ayrılan bir yer altı tüneli, İzzettin Mahallesi'nin 130, Kestanelik Mahallesi'nin 445, Çanakça Mahallesi'nin 198, Yazlık Mahallesi'nin 93 ve 559 nolu parsellerinde de betonarme bariyerler (tank mani hattı ve siperler) tespit edilmiştir.
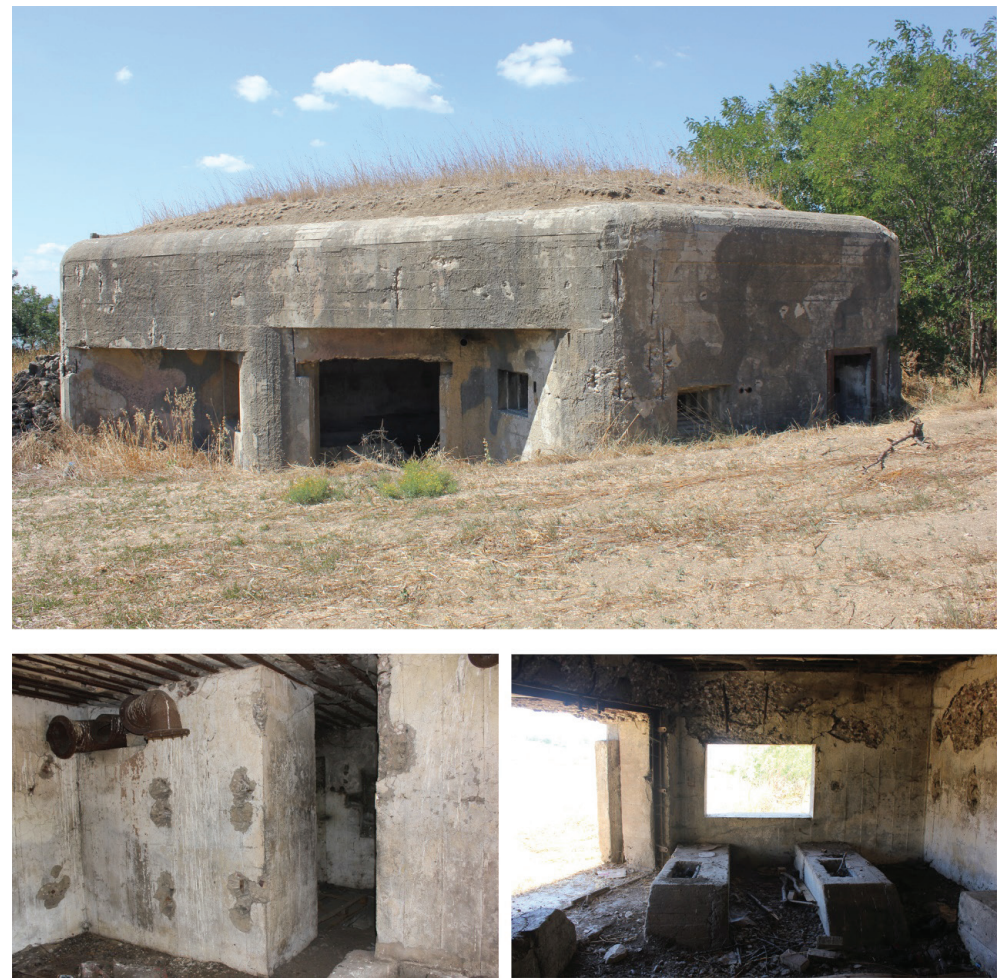

Şekil 38: Büyükçekmece ilçesi 385 ada, 4 parseldeki korugan. (M. Efeoğlu, 2020)

Savunma hattının sayıca en fazla ve karakteristik yap1 grubunu oluşturan betonarme koruganlar, dünyanın birçok yerinde ve ülkemizde inşa edilmiş çağdaşları gibi, cephelerinde çok az açıklığı bulunan kompakt betonarme yapılardır. Temelden tavan döşemesine kadar bir bütün olarak tasarlanmış bu yapılar, ahşap kalıplara demir donatının yerleştirilmesi ve betonun dökülmesiyle inşa edilmiştir. Savunma hattındaki betonarme koruganlar, Büyükçekmece'deki Mimar Sinan Köprüsü’nün doğu ucundan başlayıp, gölün doğu kıyısını takip ederek kuzeye doğru birbirine paralel iki hat olacak şekilde devam etmektedir. XIX. yüzyılda inşa edilmiş tabyalarla aynı rotayı paylaşan savunma hattı, Büyükçekmece'den kuzeye doğru sırasıyla, Karaağaç, Bahşayiş, Nakkaş, Örcünlü, Kestanelik, Çanakça ve Yazlık mahallelerinden geçerek Terkos Gölü’nün güney kıyısında sonlanır. 


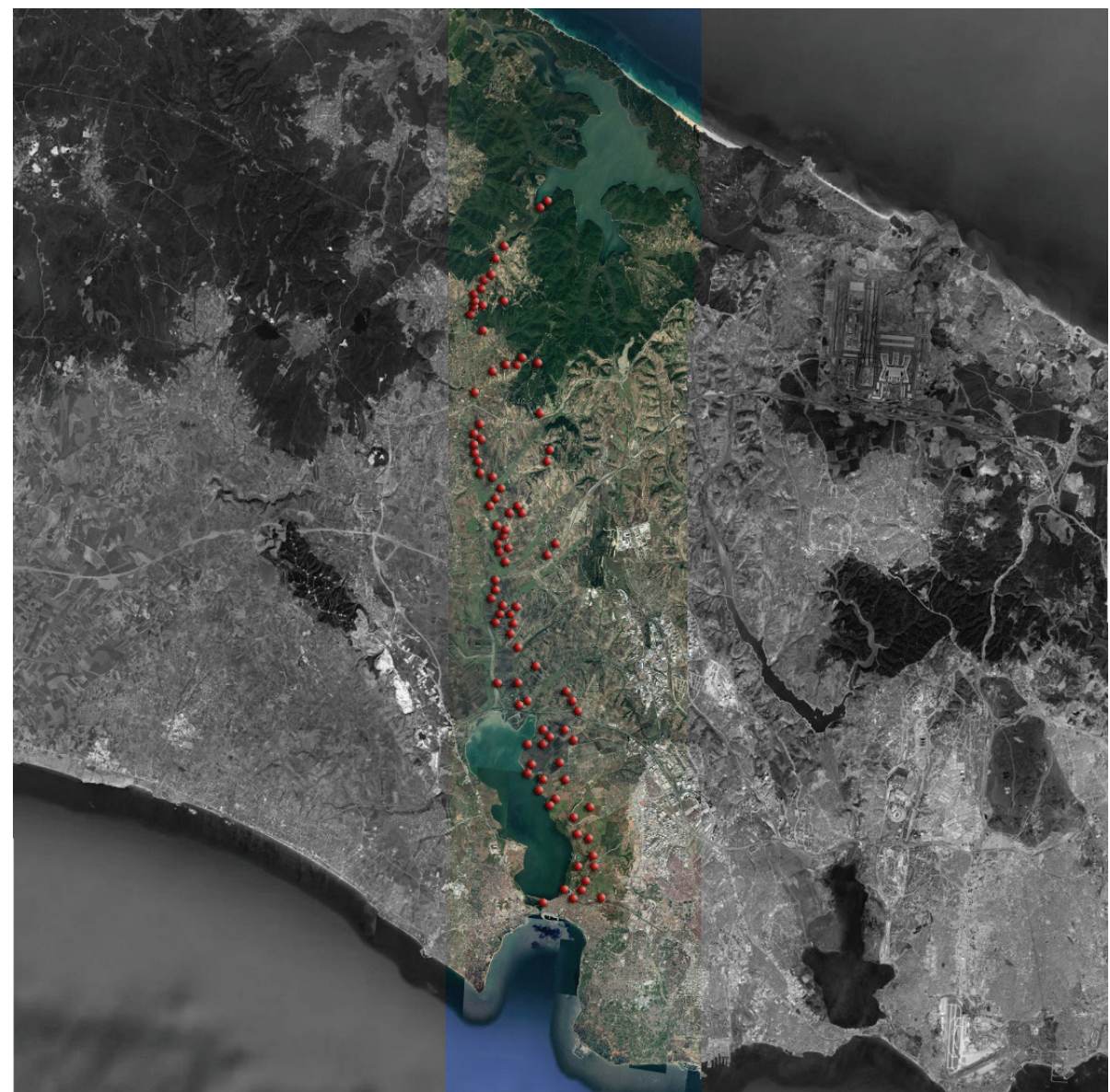

Şekil 39: Günümüze ulaşan betonarme savunma yapılarının konumları. (M. Efeoğlu, 2020)

\section{DEĞERLENDIRME VE SONUÇ}

Çatalca Bölgesi, Trakya üzerinden gelecek saldırıları engellemek amacıyla, tarih boyunca İstanbul'un savunulmasında etkili olan yerlerden biri olmuştur. Coğrafi açıdan sahip olduğu avantajlar, bölgeyi doğal bir savunma hattına dönüştürmüştür. İstanbul'a 65-70 kilometre mesafede olması, ayrıca; Karadeniz ve Marmara Denizi’ne kıyısının bulunması, bölgenin savaş dönemlerinde lojistik destek almasını kolaylaştırmıştır.

Günümüze ulaşan kalıntılarıyla varlığını sürdüren üç önemli savunma hattının ele alındığı bu çalışmada, savunma hatlarının tarihçeleri, mimari özellikleri, konumları ve mevcut durumları hakkında bilgiler verilmeye çalışılmıştır. Kendi dönemleri 
bağlamında, Çatalca Bölgesi'ndeki savunma yapıları, ülkemizde ve dünyanın birçok yerinde inşa edilmiş savunma yapılarıyla temel ortak özelliklere sahiptir. Yerleşkeleri ve insan faaliyetlerini dış tehditlere karşı korumak amacıyla bariyer ya da kalkan görevi üstlenmeleri, saldırgan grupların ilerlemesini engellemek ve yavaşlatmak için tampon bölgeler yaratmaları ve caydırıcılık özelliklerine sahip olmaları, savunma yapılarının en temel ortak özellikleridir. Bu bağlamda, Çatalca Bölgesi'ndeki savunma yapılarıyla yakın dönemde ancak, farklı bölgelerde inşa edilmiş savunma yapılarını karşılaştırdığımız zaman, yapılar arasındaki yapısal ve kuramsal benzerlikleri görmemiz mümkündür.

V. yüzyılda inşa edilen ve yaklaşık beş yüz yıl boyunca İstanbul'u batıdan gelecek saldırılara karşı korumak amacıyla kullanılan Anastasius Surları, temsil ettiği tarihsel sürecin ve inşa edildiği dönemin tipik bir örneğidir. C. Foss ve D. Winfield, "Byzantine Fortifications: An Introduction" başlıklı eserlerinde, Anastasius Suru'nun savunma sistemi açısından, Kuzey Britanya'daki Hadrian Duvarı ile benzer olduğunu ve eğer, bu yapıda tuğla malzeme kullanılsaydı Konstantinopolis'in surlarına çok benzeyeceğini belirtmişlerdir. ${ }^{89}$

Savaş taktiklerinde ve silah teknolojisinde yaşanan gelişmeler, XIV. yüzyıldan sonra surlarda, kulelerde ve kalelerde köklü dönüşümlerin yaşanmasına neden olmuş ve süreç içerisinde tabyalı tahkimatların ortaya çıkmasına yol açmıştır. İlk kez Avrupa'da ortaya çıkan tabyalı tahkimatlar, XIX. yüzyılın sonuna kadar dünyanın birçok yerinde inşa edilmiş, kent merkezlerini düşman saldırılarından uzak tutmak için kullanılan etkin savunma yapılarına dönüşmüştür. Süreç içerisinde farklı plan tipolojileri geliştirilerek dünyanın birçok bölgesinde inşa edilen tabyalı sistemler Osmanlı'da XVIII. yüzyılın sonuna doğru uygulanmaya başlanmıştır. ${ }^{90}$ III. Mustafa döneminde (1757-1774) görevli Fransız Mühendis Baron de Tott tarafından, Rus donanmasının Çanakkale Boğazı'ndan geçişini engellemek ve İstanbul'un güvenliğini sağlamak amacıyla, daha önce inşa edilen kalelere ek olarak Çanakkale Boğazı ve çevresine yeni tabyalar inşa edilmiştir. ${ }^{91}$ Ancak, Osmanlı' da tabyaların inşası, batılılaşma faaliyetlerinin de yoğun olduğu XIX. yüzyılda hız kazanmıştır. Bu dönemde, başta Çanakkale ve İstanbul boğazları olmak üzere, Edirne, Kırklareli, İstanbul, Erzurum, Kars ve Ardahan gibi yurdun önemli geçiş noktalarına ve stratejik yerlerine yeni tabyalar inşa edilmiştir. ${ }^{92}$ Çatalca Bölgesi'nde, Büyükçekmece ve Terkos gölleri arasında inşa edilen tabyalar ise, 1877-78 Osmanlı - Rus Savaşı önlemleri kapsamında inşa edilmeye başlanmış ve Balkan Savaşları'na kadar devam etmiştir. Bölgede inşa edilen tabyalar, yer seçiminden plan tipolojisi ve yapım tekniğine kadar, aynı dönemde farklı bölgelerde inşa edilmiş tabyalar ile çeşitli açılardan benzer özellik taşımaktadır. Batıdan gelecek saldırıları engellemek amacıyla, kuzey - güney yönünde, bir savunma hattı oluşturmaları, plan tipolojileri ve yapım tekniği açısından, Edirne,

89 Foss ve Winfield, 1986, 130.

90 Yeler, 2013, 31-32.

91 Acıŏlu, 2016, 3.

92 Ayrıntılı bilgi için bk. Çam, 1993; Güner, 2004; Ülkü, 2006; Küçükuğurlu, 2014; Eyüpgiller ve Yaşa, 2019. 
Kırklareli ve Çatalca Bölgesi'ndeki tabyalar, oldukça benzerdir ${ }^{93}$. Nusret Çam, XIX. yüzyılda Erzurum'da inşa edilmiş tabyaların plan özelliklerinden bahsederken, arazi eğiminin fazla olduğu, bir tepenin zirvesinde inşa edilen tabyaların dairesel, arazi eğiminin az olduğu arazilerde inşa edilen tabyaların ise lineer bir plan şemasına sahip olduğunu ifade etmiştir. ${ }^{94}$ Tabyaların inşa edileceği arazilerin seçiminde, Çatalca Bölgesi'nde de benzer uygulamanın yapıldığını söylemek mümkündür.

1940’ta Büyükçekmece ve Terkos gölleri arasında yapımına başlanan betonarme savunma yapıları ise, Çatalca Bölgesi’ndeki askeri mimari mirasın son katmanını oluşturmaktadır. XX. yüzyılın başlarında dünyanın birçok yerinde inşa edilen betonarme koruganlar, bariyerler, avcı çukurları ve tüneller, II. Dünya Savaşı'nın sembolik savunma yapıları haline gelmiştir. Türkiye Cumhuriyeti II. Dünya Savaşı’na katılmamış olmasına rağmen, dönemin hükümeti olası saldırılara karşı çeşitli önlemler almıştır. Alınan önlemler kapsamında, ülkenin stratejik açıdan önemli bölgelerine, plan özellikleri, yapım tekniği ve malzemesi, cephe biçimlenişi açısından birbirine çok benzeyen ve işlevsel özellikleri ön planda olan kompakt betonarme yapılar inşa ettirilmiştir. ${ }^{95}$ Çatalca Bölgesi'nde de, "Çakmak Hattı" olarak bilinen ve betonarme savunma yapılarından oluşan bu hat, II. Dünya Savaşı döneminin savunma yapılarını temsil etmektedir.

Kendi dönemlerinin mimari özelliklerini, yapım tekniklerini, malzemelerini ve savunma stratejilerini günümüze yansıtmaları açısından, üç savunma hattı da korunması gereken kültür varlığıdır. Ancak, bölgede yapılan tespit ve belgeleme çalışmaları sonucunda üç savunma hattının ve dolayısıyla savunma hatlarındaki yapıların korunamadığı ve ne yazık ki yok olma tehlikesiyle karşı karşıya oldukları anlaşılmıştır. Yaklaşık olarak 500 yıl boyunca çeşitli onarımlarla ayakta kalan ve Evcik Plajı'ndan Silivri'ye kadar kesintisiz bir savunma duvarı işlevi gören Anastasius Surları'nın sadece kuzeyde (Kurfallı Mahallesi'nin üç km kuzeyinden Evcik Plajı'na kadar) sık ormanlık alan içindeki bölümü günümüze ulaşmıştır. XIX. yüzyılın sonlarında inşa edilen ve Balkan Savaşları'nın bitimine kadar aktif bir şekilde kullanılan, Büyükçekmece ve Terkos Gölleri arasındaki Çatalca Savunma Hattı'na ait tabyalardan ise ancak altısının kalıntıları günümüzde varlığını sürdürmektedir. II. Dünya Savaşı önlemeleri kapsamında inşa edilen savunma hattındaki yapıların yarısına yakını yok olmuş, geriye kalan yapıların da birçoğunun yapısal elemanlarında ciddi hasar ve bozulmalar bulunmaktadır.

Bölgedeki savunma yapılarının bozulmalarına ve giderek yok olmalarına neden olan faktörlerden biri, bu yapıların; uzun yıllar boyunca her türlü doğa olayına karşı korunaksız kalmış olmalarıdır. Uzun süre doğrudan yağmur, kar ve şiddetli rüzgâra maruz kalmaları ve süreç içinde yaşanan şiddetli depremler, bölgedeki savunma yapılarında ciddi hasarların oluşmasına neden olmuştur. Doğal afetler, iklimsel ve biyolojik etkenler yapıların kâgir malzemelerinde parça kopmalarına, yüzey erozyonlarına ve strüktürel

93 Güner, 2004, 87-111; Yeler, 2013, 449-470.

94 Çam, 1993, 164.

95 Ayrıntılı bilgi için bk. Arslan, 2004; Arıkboğa, 2019; Ocak ve Tekin, 2019; Aydın, 2020. 
çatlakların oluşmasına neden olan temel faktörlerdir. Ayrıca, savunma yapılarının kullanım amaçlarının son bulmasıyla terk edilmeleri ve bir süre sonra da herhangi bir bakımın ya da onarımın yapılmaması, bozulmanın hızlanmasına yol açmıştır.

Çatalca Bölgesi'nde devam eden büyük ölçekli yol projeleri ve kuzeye doğru yoğun yapılaşma gibi bayındırlık faaliyetlerinin dışında, kötü kullanım ve uygun olmayan müdahaleler savunma hatlarını tehdit eden bir başka koruma sorunudur. Alan çalışmaları sırasında birçok savunma yapısının yıkılarak tarım arazisine dönüştürüldüğü, yapıların içinde ateş yakıldığı ve define avcıları tarafından derin çukurların kazıldığı tespit edilmiştir.

Günümüzde, Anastasius Surları, birinci derece arkeolojik sit alanı olarak, tabya ve koruganların ise bir bölümü ${ }^{96}$ ilgili koruma kurulu tarafindan tescillenerek koruma altına alınmıştır. Yasal olarak koruma altına alınmalarına karşın bu yapılar üzerindeki tahribat günümüzde de devam etmektedir. Günümüze ulaşan savunma yapıları ancak sürdürülebilir koruma önerileri ve uygulamaları ile varlığını devam ettirebilir. Bu kapsamda, seçmeci bir yaklaşımdan uzak, savunma yapılarının tamamı yasal olarak koruma altına alınmalı ve bir denetim mekanizması oluşturularak yapılardaki tahribatın önünü geçilmelidir. Ayrıca, savunma yapılarında bozulmalara ve hasarlara neden olan faktörlerin ayrıntılı bir şekilde saptanması, yapılacak koruma müdahalelerinin yapı özelinde olması ve yakın çevrenin de dâhil edildiği bütüncül koruma uygulamalarının hayata geçirilmesi gerekmektedir.

96 İstanbul I Numaralı Kültür Varlıklarını Koruma Bölge Kurulu'nun almış olduğu, 13.08.2015/1479, 23.06.2016/1938, 10.11.2016/2115, 29.12.2016/2193, 09.02.2017/2272, 02.03.2017/2310, 09.03.2017/2332 ve 22.02.2018/3208-1 tarihli ve numaralı kararlarla tescillenmiş yapılar. 


\section{KAYNAKÇA}

Acıoğlu, Y. (2016). Çanakkale Tabyaları, Sanat Tarihi Dergisi, 25(1), 1-57.

Altunan, S. (2005). XVIII. yy’da Silistre Eyaletinde Haberleşme Ağı: Rumeli Sağ Kol Menzilleri, Ankara Üniversitesi Osmanlı Tarihi Araştırma ve Uygulama Merkezi Dergisi, 1-20.

Aksun, Z. N.(1930). Osmanlı Tarihi, Osmanlı Devleti'nin Tahlilli, Tenkidli Siyasi Tarihi (C. 5, 494-495), İstanbul: Ötüken Neşriyat.

Andreossy, C. (1818). Voyage de la Mer-Noire, ou Essai Sur Le Bosphore, Paris.

Arıkboğa, C. (2019). Bunker-scape: Defense Architecture in Gallipoli Peninsula I Korugan-Peyzaj: Gelibolu Yarımadasindaki Savunma Mimarisi, (Yayımlanmamış Yüksek Lisans Tezi), Orta Doğu Teknik Üniversitesi, Fen Bilimleri Enstitüsü, Ankara.

Armaoğlu, F. (1958). I İkinci Dünya Harbi’nde Türkiye, Ankara Üniversitesi SBF Dergisi,13(2), 139-179.

Aslan, D. (2004). Özellikle Büyükçekmece Koruganları, Betonart Dergisi, (4), 55.

Aydın, S. (2020). İkinci Dünya Savaşı'nda Kıyı ve İç Hat Savunması: Çakmak Hattı (Büyükçekmece-Çatalca) Koruganları, Güvenlik Stratejileri Dergisi, 16(34), 383-451.

Bagster, S. (1846). Ecclesiastical History, A History of The Churcrh, In Six Books, from A.D. 431 to A.D. 594 by Evagrius, London.

Burke, A. A. (2004). The Architecture of Defense: Fortified Settlements of The Levant During The Middle Bronze Age, (Unpublished Doctor of Philosophy Thesis), University of Chicago, Chicago, Illinois.

Foss. C, ve Winfield, D. (1986). Byzantine Fortifications an Introduction, University of South Africa, Pretoria.

Coppin, P. J. (1686). Le Bouclier De L'Europe ou La Guerre Sainte, De Voyages Faits Dans La Turquie, Lyon.

Couto, D. (2016). İstanbul Boğazı'ndaki Osmanlı Hisarları, Üç Denizin Arasında, İzmir: Arkadaş Matbaacılık.

Croke, B. (1981). The Date of the “Anastasian Long Wall” in Thrace, 59-78, Macquarıe University, Sydney.

Crow, J. (1995). The Long Walls of Thrace, Constantinople and Its Hinterland, Great Britain: Ashgate Publishing.

Crow, J. Ricci, A. (1997). Investigating The Hinterland Of Constantinople: Interim Report On The Anastasian Long Wall, Journal Of Roman Archaeology, 10, 235-263.

Çadırcı, M. (1989). II. Abdülhamit Döneminde Osmanlı Ordusu, Ankara: Genelkurmay Askeri Tarih ve Stratejik Etüt Başkanlığı Yayınları.

Çam N. (1993). Erzurum Tabyaları, Ankara: Kültür Bakanlığg Yayınları. 
Çetin, S. (2013). İkinci Dünya Savaşı'nda İstanbul ve Trakya'nın Tahliye Edilmesi, Atatürk Yolu Dergisi (52), 771-802.

Dikici, R. (2016). The History of Byzantine Empire (Byzantium 330-1453), İstanbul: Remzi Kitapevi.

Dirimtekin, F. (1948). Anasthase Surları, TTK Belleteni, 12(45), 1-10.

Donnell, C. (2008). The German Fortress Of Metz 1870-1944, Oxford: Osprey Publishing.

Downey, G. (1971). Procopius, Buildings General Index to Procopius, London: Harvard University Press.

Erickson, E. D. (2013). Büyük Hezimet, Balkan Harplerinde Osmanlı Ordusu, İstanbul: Türkiye İş Bankası Kültür Yayınları.

Eyice, S. (2001). Kale, T.D.V. İslam Ansiklopedisi, (C. 24, 234-242), Ankara.

Eyice, S. (1980). Trakya Araştırmacılarından: Feridun Dirimtekin 1894-1976, Güneydoğu Avrupa Araştırmaları Dergisi, 8, 259-285.

Eyüpgiller, K. K. ve Yaşa, Y. (2019). İstanbul Bahr-i Siyah / Karadeniz Boğazı Kale ve Tabyaları, İstanbul: Kitabevi Yayınları.

Firatlı, N. (1979). Trakya'da Anastasius Surları Denilen Uzun Duvar, TTOK Belleteni, 63(343), 21-22.

Ford, K. (2012). The Mareth Line 1943, The end in Africa, Oxford: Osprey Publishing.

Gimpel, J. (2005). Ortaçağda Endüstri Devrimi, TÜBi̇TAK Popüler Bilim Kitapları, Ankara: Yenigün Matbaası.

Greene, F. V. (1879). The Russian Army and Its Campaigns in Turkey in $1877-$ 1878, New York.

Güner, Y. (2004). Edirne Askeri Tabyalarının Mimarisi, (Yayımlanmamış Yüksek Lisans Tezi), Mimar Sinan Güzel Sanatlar Üniversitesi, Sosyal Bilimler Enstitüsü, İstanbul.

Gürün, K. (1988). Türkiye'yi II. Dünya Savaşı'na Sokma Çabaları, TTK Belleteni, 52 (204), 1455-1468.

Gyllius, P. (1997). İstanbul'un Tarihi Eserleri, İstanbul: Eren Yayıncılık.

Hall, R. C. (2003). The Balkan Wars 1912-1913, London: Published by Routledge.

Hart, B. L. (2009). İkinci Dünya Savaşı Tarihi, İstanbul: Türkiye İş Bankası Kültür Yayınları.

Harrison, R. M. (1969). Trakya'da Uzun Duvar, Türk Arkeoloji Dergisi, (18), 7783.

Hasol, D. (1990). Ansiklopedik Mimarlık Sözlüğ̈̈, İstanbul: Yapı Endüstri Merkezi Yayınları.

Kahraman, S. A. ve Dağlı, Y. (2006). Günümüz Türçesiyle Evliyâ Çelebi Seyahatnamesi (C.3, 385), İstanbul: Yapı Kredi Yayınları. 
Kanberoğlu, N. (2018). Osmanlı Devleti'nin II. Meşrutiyet Dönemi Demiryolu Politikaları 1908-1914, Vakanüvis - Uluslararasl Tarih Araştırmaları Dergisi, Prof. Dr. Azmi Özcan Öğrencileri Özel Sayıs, 158-187.

Karaca, E. (2020). Arkeolojik Verilere Göre Doğu Trakya Kuzey Yolu, Belleten, 84(299), 29-42.

Karpuz, H. (2004). Anadolu Selçuklu Mimarisi, Konya: Selçuk Üniversitesi Basimevi.

Keegan, J. (1993). A History of Warfare, New York: Random House.

Keeley, L., H., Fontana, M., ve Quick, R., (2007). Baffles and Bastions: The Universal Features of Fortifications, Journal of Archaeological Resource 15, 15-95.

Küçükuğurlu, M. (2014). Erzurum Tabyaları ve Klşlaları, Erzurum: Erzurum Büyükşehir Belediyesi Kültür Yayınları.

Lechevalier, J. B. (1800). Voyage de la Propontide et du Pont-Euxin, Paris.

Lendy, A. F. (1857). Elements of Fortification: Field and Permanent, For Use of Students, Civilian and Military, London.

Lendy, A. F. (1862). Treatise on Fortification or Lectures Delibered to Officers Reading for The Staff, W. Mitchell, Military Bookseller 39, London: Charing Cross.

Lepage, J. D. (2002). Castles and Fortified Cities of Medieval Europe :An Illustrated History, London: McFarland \& Company.

Lepage, J. D. (2010). Vauban and the French Military Under Louis XIV: An Illustrated History of Fortifications and Strategies, London.

Lynch, C. (2003). Niccolo Machiavelli, Art of War, London: The University of Chicago Press.

Mansel, A. M. (1938). Trakya'nın Kültür ve Tarihi, İstanbul: Edirne ve Yöresi Eski Eserleri Sevenler Kurumu Yayını.

Millingen, A. V. (1899). Byzatine Constantinople, The Walls of The City and Adjoining Historical Sites, London.

Müth, S., Sokolicek, A., Jansen, B., Laufer, E. (2016). Ancient Fortifications: A Compendium of Theory and Practice, Methods of Interpretation, Oxford: Oxbow Books.

Nossov, K. S. (2008). Hittite Fortifications c. 1650-700 BC, New York: Osprey Publishing.

Ocak, M. T. ve Tekin, Ö. F. (2019). Anadolu Feneri Koruganları, Betonart Dergisi, 15(60), 66-71.

Ödekan, A. (1997). Kale, Eczacıbaşı Sanat Ansiklopedisi, (C.2, 932-933), İstanbul: Yem Yayınları. 
Özgüven, H. B. (1997). Barut ve Tabya: Rönesans Mimarisi Bağlamında Fatih Sultan Mehmet Kaleleri, (Yayımlanmamış Doktora Tezi), İstanbul Teknik Üniversitesi, Sosyal Bilimler Enstitüsü, İstanbul.

Özgüven, B. (2001). The Palanka: A Characteristic Building Type of the Ottoman Fortification Network in Hungary, (Proceedings of the 11th International Congress of Turkish Art, Utrecht- The Netherlands, August 23-28, 1999), EJOS, Vol: IV, No: 34, Netherlands 2001, $1-12$.

Parker, G. (2014). Cambridge Savaş Tarihi, İstanbul: Türkiye İş Bankası Kültür Yayınları.

Philippides, M. (2011). The Siege and Fall of Constantinople in 1453: historiography, topography and military studies, USA, Amherst: Routledge.

Portlock, M. G. (1858). Papers on Geometrical Drawing, On The Arms is Use and Permanent Fortification, On The Attack and Defence of Fortresses, On Military Mining, and on The Defence of Coasts, London: George Edward Eyre and William Spottisswoode, Printers to The Queen's Most Excellent Majesty, John Weale 59, High Holborn.

Schuhhardt, C. (1901). Die Anastasius-Mauer bei Constantinopel und die Dobrudshca-Walle, JDAI 16, 107-115.

Sevgen, N. (1960). Anadolu Kaleleri, Ankara: Doğuş Ltd. Şirketi Matbaası.

Sözen, M. ve Tanyeli, U. (1986). Sanat Kavram ve Terimleri Sözlüğü, İstanbul: Remzi Kitabevi.

Tekeli, İ. ve İlkin, S. (2014). İktisadi Politikaları ve Uygulamalarıyla İkinci Dünya Savaşı Türkiye'si, İstanbul: İletişim Yayınları.

Troçki, L. (2012). Balkan Savaşları, İstanbul: Türkiye İş Bankası Kültür Yayınları.

Tuncer, H. (2012). İsmet İnönü’nün Dış Politikası, (1938-1950) İkinci Dünya Savaşı'nda Türkiye, İstanbul: Kaynak Yayınları.

Ülkü, O. (2006). Kars ve Ardahan Tabyaları, (Yayımlanmamış Doktora Tezi) Atatürk Üniversitesi, Sosyal Bilimler Enstitüsü, Erzurum.

Weisband, E. (2000). İkinci Dünya Savaşı’nda İnönü'nün Dış Politikası, İstanbul: Çağdaş Matbaacılık ve Yayıncılık.

Whitby, M. (1985). The Long Walls Of Constantinople, Byzantion, 55(2), 560583.

Yeler, S. (2013). Trakya Bölgesi Tabyalarl: Koruma Sorunlarl ve Koruma Kullanma Önerileri, (Yayınlanmamış Doktora Tezi), Trakya Üniversitesi, Fen Bilimleri Enstitüsü, Edirne.

Zaloga, S. J. (2007). The Atlantic Wall (1) France, Oxford: Osprey Publishing. 


\begin{abstract}
Arşiv
BOA, Y..PRK. ASK, Kutu No:2, Gömlek:39, Hicri: 17.12.1295

BOA, BEO., Kutu No: 4140, Gömlek: 310484, Hicri: 14.11 .1330

BOA, MV., Kutu No: 171, Gömlek: 15, Hicri: 06.12.1330

BOA, Y. MTV., Kutu No: 49, Gömlek: 9, Hicri: 03.08.1308

BOA, MV., Kutu No: 171, Gömlek: 1, Hicri: 01.12.1330

BOA, HRT.h., Kutu No: 2170, Hicri: 10.03.1289

BCA, Kutu No: 88, Gömlek: 97, S1ra: 6, Miladi: 03.10.1939

BCA, Kutu No:90, Gömlek:23, Sıra: 2, Miladi: 09.03.1940

BCA, Kutu No:91, Gömlek:61, Sira: 4, Miladi: 24.06.1940

BCA, Kutu No:92, Gömlek:73, Sıra: 19, Miladi: 23.07.1940

BCA, Kutu No:92, Gömlek:86, Sıra: 3, Miladi: 10.09.1940

BCA, Kutu No:95, Gömlek:59, Sira: 4, Miladi: 10.07.1941

BCA, Kutu No:93, Gömlek:125, Sıra: 8, Miladi: 21.01.1941

BCA, Kutu No:98, Gömlek:25, Sira: 17, Miladi: 27.03.1942

BLH, Sira No: 185, Kutu No: 11, Gömlek: 4, Rumi: 1327

BDH, Sıra No: 7, Kutu No: 616, Gömlek: 36, Rumi: 1330

İstanbul Üniversitesi, Nadir Eserler Kütüphanesi, Demirbaş No: 92518

İstanbul Üniversitesi, Nadir Eserler Kütüphanesi, Demirbaş No: 93178
\end{abstract}


Ege Üniversitesi, Edebiyat Fakültesi Sanat Tarihi Dergisi ISSN $1300-5707$ Cilt: 30, Sayı: 1 Nisan 2021
Ege University, Faculty of Letters Journal of Art History e-ISSN 2636-8064 Volume: 30, Issue: 1 April 2021

\section{İternet Sayfası (Aclk Erisim) | Internet Page (Open Access) \\ DergiPark \\ https://dergipark.org.tr/std}

Sanat Tarihi Dergisi hakemli, bilimsel bir dergidir; Nisan ve Ekim aylarında olmak üzere yılda iki kez yayınlanır.

Lournal of Art History is a peer-reviewed, scholarly, periodical journal published biannually, in April and October. 